IZA DP No. 10369

Job Creation Schemes in Turbulent Times

Annette Bergemann

Laura Pohlan

Arne Uhlendorff

November 2016 


\title{
Job Creation Schemes in Turbulent Times
}

\author{
Annette Bergemann \\ University of Bristol, IFAU und IZA
}

Laura Pohlan

University of Mannheim and ZEW

Arne Uhlendorff

CREST, CNRS, Unversité Paris-Saclay, IAB, IZA and DIW

\section{Discussion Paper No. 10369 \\ November 2016}

\author{
IZA \\ P.O. Box 7240 \\ 53072 Bonn \\ Germany \\ Phone: +49-228-3894-0 \\ Fax: +49-228-3894-180 \\ E-mail: iza@iza.org
}

\begin{abstract}
Any opinions expressed here are those of the author(s) and not those of IZA. Research published in this series may include views on policy, but the institute itself takes no institutional policy positions. The IZA research network is committed to the IZA Guiding Principles of Research Integrity.

The Institute for the Study of Labor (IZA) in Bonn is a local and virtual international research center and a place of communication between science, politics and business. IZA is an independent nonprofit organization supported by Deutsche Post Foundation. The center is associated with the University of Bonn and offers a stimulating research environment through its international network, workshops and conferences, data service, project support, research visits and doctoral program. IZA engages in (i) original and internationally competitive research in all fields of labor economics, (ii) development of policy concepts, and (iii) dissemination of research results and concepts to the interested public.
\end{abstract}

IZA Discussion Papers often represent preliminary work and are circulated to encourage discussion. Citation of such a paper should account for its provisional character. A revised version may be available directly from the author. 
IZA Discussion Paper No. 10369

November 2016

\section{ABSTRACT \\ Job Creation Schemes in Turbulent Times*}

This paper analyzes the impact of job creation schemes (JCS) on job search outcomes in the context of the turbulent East German labor market in the aftermath of the German reunification. High job destruction characterized the economic environment. JCS were heavily used in order to cushion this development. Using data from 1990-1999 and building upon the timing-of-events approach, we estimate multivariate discrete time duration models taking selection based on both observed and unobserved heterogeneity into account. Our results indicate that participation in JCS increases the unemployment duration mainly due to profound locking-in effects. However, twelve months after the program start the significantly negative impact on the job finding probability vanishes. We find evidence for effect heterogeneity. Our results suggest that female and highly skilled participants leave unemployment quicker than other groups, which results in highly skilled women benefiting from participation. However, we find no significant impact on post-unemployment employment stability. Our results are robust to allowing for random treatment effects. Also taking into account endogenous participation in training programs or multiple treatment effects do not change the results.

JEL Classification: J64, C41, C33

Keywords: $\quad$ active labor market policy, unemployment duration, employment stability, timing-of-events model, East Germany, transition economy

Corresponding author:

Arne Uhlendorff

CREST

15 boulevard Gabriel Péri

92245 Malakoff Cedex

France

E-mail: arne.uhlendorff@ensae.fr

\footnotetext{
* We thank Stephen Kastoryano, Konrad Stahl and the participants of seminars at ZEW and at the University of Mannheim for valuable comments. The paper has benefited from discussions at the conferences of the European Economic Association, Geneva, of the Verein für Socialpolitik, Augsburg and of the European Association of Labour Economists, Ghent.
} 


\section{Introduction}

This paper analyzes the impact of job creation schemes (Arbeitsbeschaffungsmaßnahmen, JCS) on job search outcomes in the context of the turbulent East German labor market in the aftermath of the German reunification. The East German economy plunged into a deep recession immediately after the German reunification in 1990. The transition from a centrally planned to a market-based economic system led to plant closures and mass-layoffs, leading to a sharp increase in the unemployment rate from virtually zero in 1990 to about 10\% in 1991. Active labor market policies (ALMP) were implemented on a large scale to fight the unemployment crisis. Hereby, job creation schemes that offer temporary work opportunities for the unemployed in the public and nonprofit sector played a prominent role. These schemes reached an all-time high in 1992 when on average 388,000 individuals were employed in JCS and expenditures of the German Federal Government and the German Federal Employment Agency amounted to 10.4 billion DM (7.8 billion $€$ in 2015 prices) in East Germany (Spitznagel 1992). This sum is equivalent to $4.4 \%$ of the East German GDP. ${ }^{1}$

There are at least two potential channels of how JCS might improve the employment situation of the participants. By providing work experience JCS can increase the attachment of the participants to the labor market. This stronger bond might motivate the participants to intensify their search effort for a regular job and increase their ability to stay on a regular job. The second channel consists of the potential ability of JCS to increase the rate at which participants receive a job offer. Naturally, job seekers become more attractive for employers if their human capital is raised and JCS offer a number of possibilities to achieve this. First of all, participation in a JCS might stop the accelerated depreciation of human capital which would occur if the participants were unemployed. By providing work experience, JCS also foster noncognitive skills. In addition, participants acquire cognitive skills by learning-on-the-job and short training courses, which are sometimes offered in the context of JCS. Participation in JCS might also offer the possibility to participants to signal their positive work attitude to potential employers. These two channels might be more effective in heavily changing economies. In our context of the East German transformation process, for example, the distance to the labor market might be larger for the unemployed and the loss of human capital might be more severe. Consequently, JCS have quite some leverage to improve the situation of the participants.

There exist a number of empirical studies evaluating the employment effects of JCS for stable, rather matured market economics. ${ }^{2}$ The general notion is that JCS do not have positive effects. However, there are some signs for effect heterogeneity. Some papers conclude that

\footnotetext{
${ }^{1}$ Bundesanstalt für Arbeit (1993) and Statistisches Jahrbuch für die Bundesrepublik Deutschland (1993).

${ }^{2}$ See for example Cockx and Ridder (2001) for Belgium, Bonnal, Fougère, and Sérandon (1997) for France, Lalive, van Ours, and Zweimüller (2008) for Switzerland and for Germany Hohmeyer and Wolff (2012) as well as the series of papers using an administrative sample of unemployed in 2000 (see Hujer, Caliendo, and Thomsen (2004), Caliendo, Hujer, and Thomsen (2006), Hujer and Zeiss (2007), Caliendo, Hujer, and Thomsen (2008a), Caliendo, Hujer, and Thomsen (2008b) and Hujer and Thomsen (2010)). For overview studies see for example Bergemann and van den Berg (2008) and Card, Kluve, and Weber (2010).
} 
long-term unemployed gain from participation in JCS, whereas others not (see for example Caliendo, Hujer, and Thomsen (2008a) vs. Hujer and Thomsen (2010)). Quite stable results exist with respect to positive effects for hard-to-place ${ }^{3}$ women in West-Germany (Caliendo, Hujer, and Thomsen (2008b) and Hohmeyer and Wolff (2012)).

The evidence is different for economies that underwent a major shock, as it was the case during the transformation process. There exist only few studies that evaluate the employment effects of JCS and those come to rather diverse results. Concerning the impact of JCS in East Germany for the period after the reunification, Hübler (1997) and Kraus, Puhani and Steiner (2000) conclude that JCS have a rather negative impact on the employment probability of the participants, while Eichler and Lechner (2002) find a substantial decline in the unemployment probability due to participation in JCS in the period after program end.

The evidence is similarly scarce when considering other transformation countries. One exception is Lubyova and van Ours (1999), who evaluate JCS for the time from 1991 to 1996 in Slovakia. They find positive effects on the job finding probability for JCS in the public sector, while JCS in the private sector that typically had a longer duration seem to reduce the exit rate to regular work. In a related paper, van Ours (2004) finds evidence that part of the difference in the effects are driven by locking-in effects of JCS, and that those are stronger for men than for women. Kluve, Lehmann, and Schmidt (1999) study the effects of different ALMP in the period from 1992 to 1996 in Poland and they find evidence for reduced employment rates mainly among male participants in JCS. ${ }^{4}$

Our analysis is based on the Labor Market Monitor Sachsen-Anhalt (LMM-SA), which is a survey on the working age population of the East German state of Sachsen-Anhalt. We use the last three waves $(1997,1998,1999)$ of the survey which include retrospective monthly calendars on the complete labor market history including participation in ALMP since the reunification. This calendar offers unique possibilities for the empirical analysis of program participation in the years after the German reunification. Our observation period starts in 1990, shortly before the reunification, and ends in $1999 .^{5}$

The program was in place in all regions in East Germany, and the data does not contain instrumental variables which could be used to identify causal effects. We therefore estimate discrete time duration models following the timing-of-events approach (Abbring and van den Berg 2003). This approach allows to control for dynamic selection into the treatment based on both observed and unobserved characteristics. We estimate the impact of JCS on the prob-

\footnotetext{
${ }^{3}$ Measured for example by a high number of unsuccessful placement propositions or dependency on welfare benefits.

${ }^{4}$ Based on Polish data Puhani (2002) presents similar findings applying matching estimators. His findings based on duration models indicate significantly negative effects for men and women. However, the estimated specifications are very restrictive. For example, he does not control for selection into the treatment and the models assume a homogenous treatment effect over time spent in unemployment.

${ }^{5}$ Eichler and Lechner (2002) also use the Labor Market Monitor Sachsen-Anhalt, but do not make use of the monthly retrospective calendar. Instead they exclusively use the current employment status that is given at the time of the yearly interviews from 1992-1997.
} 
ability of finding a job and on the probability of retaining employment. This approach has two major advantages in particular in view of evaluating a program in an unstable economy. Firstly the way how we allow for selection on unobserved heterogeneity does not require controlling for past employment outcomes or using past employment outcomes in order to estimate differences-in-differences (as e.g. Caliendo, Hujer, and Thomsen (2008a) or Eichler and Lechner (2002)). Besides a lack of availability of detailed data on employment histories before 1990, this type of data might contain relatively little information for the prediction of future outcomes in our observation period. The unemployment rate in the socialistic German Democratic Republic (GDR) was close to zero and a large share of the human capital has lost its value during the transformation process. Therefore, in our application using the timing-of-events approach delivers new insights into the effectiveness of JCS.

The second major advantage of our approach is the focus on transition rates. This takes automatically into account that the program does not take place in a stationary environment. Bergemann, Fitzenberger, and Speckesser (2009) show for the case of training in East Germany that using transition rates as success indicator is more appropriate in such a nonstationary environment as compared to the use of unconditional employment rates as it is often done in the literature. Furthermore estimating the effects on transition rates is more informative because they deliver detailed information about the functioning of JCS; notably, whether the program helps participants to find a regular job and whether the program helps to stay in a regular job. This is particularly interesting for the German case, as the regulatory framework sets down that JCS should help to improve the employment situation notably in these two dimensions.

The studies closest to ours is van Ours (2004). His evaluation approach also builds upon the timing-of-events approach, but he solely focuses on the transition rate to work. Moreover, he investigates effect heterogeneity only with respect to gender. We investigate effect heterogeneity with respect to selected further characteristics like education, and estimate models allowing for effect heterogeneity with respect to unobserved characteristics following Richardson and van den Berg (2013) in order to capture additional heterogeneities in the effects. Moreover, we estimate specifications controlling for endogenous participation in training programs and investigate the effects of multiple treatments.

Our results suggest strong negative locking-in effects during program participation. In a model with homogeneous treatment effects, the negative treatment effect vanishes one year after the program start. Furthermore we show that women and highly skilled participants leave unemployment quicker than other groups, which results in highly skilled women benefiting from participation. Additional results suggest that JCS do not influence employment stability.

The rest of the paper is structured as follows. Section 2 describes the East German labor market situation and the institutional settings of JCS. Section 3 presents the data and descriptive statistics. Section 4 specifies the empirical model and discusses the underlying assumptions. Section 5 presents the results of the empirical analysis and Section 6 concludes. 


\section{Institutional Background}

\subsection{Economic Development in East Germany}

On the eve of the German reunification in 1990, the economic situation in East Germany was quite desolate. The centrally planned economy of the GDR was characterized by inefficient production processes, obsolete technologies and over-staffing. Following a policy of full employment, the GDR had a labor force of about 10 million in 1989 and unemployment was almost non-existing. In contrast, the modern market-oriented economy of the Federal Republic of Germany had a labor force of about 28 million and a rate of registered unemployment of $7.9 \%$ in 1989 (Federal Employment Agency, 2014). ${ }^{6}$

In this new environment existing firms faced enormous difficulties to compete. They could rarely cover their variable costs at the prevailing market prizes. In addition, their former home market broke away as East Germans diverted their spending towards West German products. Production in 1991 only reached 2/3 of its 1989 level. Four years of high growth rates followed. However, since 1996 the economy was basically stagnating again.

The government reacted with setting up large labor market programs in order to cushion the effects of economic restructuring. Shortly after the reunification the main emphasis was put on instruments that were easy to implement. Short-time work and early retirement schemes were predominant. However, already in 1991, a substantial part of the East German labor force participated in active labor market programs to keep the official unemployment rate - which does not include program participants - from skyrocketing. By correcting the number of unemployed by the number of participants in ALMP programs, unemployment rates in East Germany amounted to $25.3 \%$ in 1991 , peaked at $35.3 \%$ in 1992 and decreased to a value of $22.8 \%$ in 1999 (see Table 1). In 1991, 209,000 individuals participated in JCS and 280,000 in training programs. Participation in ALMP measures peaked in 1992 with over 800,000 individuals participating on average in full-time programs. From 1993 onwards, the number of participants began to shrink due to policy changes and financial restrictions. However, training and JCS remain important components of policy interventions in East Germany until the early 2000s.

Despite the heavy use of ALMP, unemployment increased drastically. During the period 1990-1992, regular employment was reduced from a yearly average of over 9 million jobs down to just under 6 million jobs and the unemployment rate rose from virtually zero in 1990 to more than $10 \%$ in 1991. From 1991 onwards, it exceeded the average unemployment rate for Germany as a whole (see Figure 1).

Our analysis is based on data gathered in the new federal state of Sachen-Anhalt. In 1999, 2.7 million individuals lived in Sachsen-Anhalt which corresponds to 3\% of the population in Germany and to $22 \%$ of the population of the new federal states without Berlin (Federal Statistical Office, 2014). Figure 1 shows that the unemployment rate in Sachsen-Anhalt exceeded the

\footnotetext{
${ }^{6}$ For more detailed information on the economic development of East Germany see von Hagen, Strauch, and Wolff (2002), Burda and Hunt (2001) and Wunsch (2005).
} 
average of East Germany over the whole observation period. These figures were mainly driven by the high concentration of manufacturing sectors like agriculture, electrical industry, trade, mining and chemical industry. After reunification, many companies in these fields had to close down due to the loss of trading partners in the East and inefficient production processes.

Figure 1: Unemployment rate in Germany 1991-1999

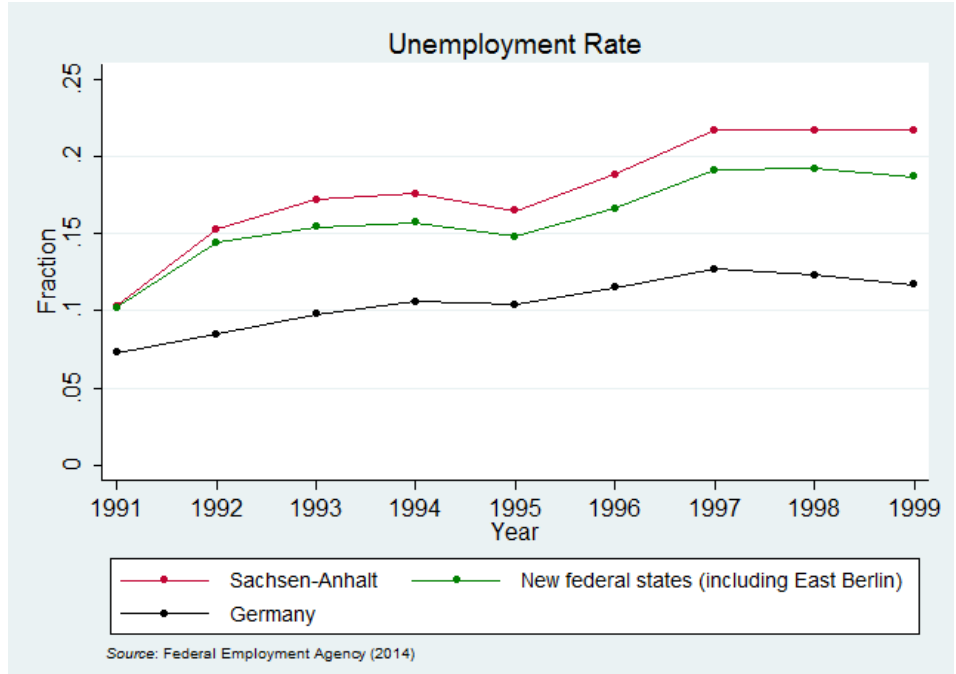

A factor that should not be neglected when discussing the economic situation in East Germany is the emigration that set in after the fall of the wall. In 1989 and 1990 almost 400,000 individuals, which is about $2 \%$ of the East German population, migrated from East to West Germany each year (Kröhnert and Skipper 2010). The threat of mass emigration was a popular argument for a quick catch-up of East German wages and for an implementation of large ALMP programs among both politicians and union leaders. Indeed, the migration situation changed after 1990. Emigration reduced substantially and was increasingly matched by immigrating West Germans. In 1997, East-West migration reached a minimum with 13,000 individuals. Since then, emigration from the new federal states has increased again.

\subsection{Background and Aims of JCS}

When the West German Employment Promotion Act (Arbeitsförderungsgesetz, AFG) was transferred to East Germany a number of additional regulations were introduced to take into account the special situation of the East German economy. Those exception meant, among others, less restrictive rules for participation in programs of ALMP shortly after reunification. In the following, we describe the eligibility rules and some important implementation details of the two different JCS programs which were realized in East Germany. We focus on the institutional regulations in force during the time before the Employment Promotion Act was replaced by the new Social Law Book III in 1998. This time period covers the main part of our observation 
period. $^{7}$

In this study, the phrase job creation scheme includes two different types of programs which were realized in East Germany after the reunification: traditional JCS (Allgemeine Maßnahmen zur Arbeitsbeschaffung, see $§ 91-96$ EPA) and Productive Wage Subsidies East (Produktive Lohnkostenzuschüsse Ost, see $\$ 249 \mathrm{~h}$ EPA). ${ }^{8}$ The latter were introduced in January 1993 and offered temporary employment opportunities in activity areas like social services or environmental redevelopment. Both job creation programs intended to create additional temporary jobs primarily in the public or non-profit sector for the time of the subsidy and were similarly handled by the labor offices. They differed, however, with respect to the level of the subsidy, program durations and the activity areas.

The government pursued several objectives by implementing JCS in East Germany in the period after reunification. First, in the course of the transformation process, JCS should simply provide jobs and income for unemployed individuals and those who were at risk of becoming unemployed. In this way the threat of social hardship could be reduced and the official unemployment rate could be lowered. Second, they were used as means to invest in the East German industrial infrastructure. Especially in the time of 1993-1996, this aim was emphasized by the large scale provision of ordinary productive wage subsidies with their restricted activity areas. The third objective which over time increasingly gained importance was the traditional aim of ALMP measures. The employment subsidies should help the participants to find regular jobs. In addition, the $A F G$ emphasized that especially those JCS should be supported which help creating stable employment relationships. This paper evaluates whether JCS help to find and retain regular employment. Hereby, traditional JCS and ordinary productive wage subsidies will be jointly evaluated. Unfortunately, data limitations make it impossible to distinguished between these two different program types (see section 3.1).

\subsection{Institutional Provisions of JCS}

The implementation of the two types of JCS involved the following steps. A project organizing institution, which could be a firm, a public authority or a charity, had to create at least one job within a project. This project needed to be beneficial for the community and had to be additional in the sense that it would not be carried out without the subsidy. Formally, after approval of a project, the local labor office should choose the participants. Surveys in labor offices showed that the time elapsing between the application of a project organizing institution and the actual program start was on average three months (Völkel (1994)). In East Germany so-called "Societies for Employment Promotion and Structural Development" (ABS-Gesellschaften) often acted as large scale organizers of JCS. In the early 90s these societies had a significant influence

\footnotetext{
${ }^{7}$ Further information and data on JCS in East Germany in the early 1990s can be found, for example in Brinkmann and Völkel (1992) and Spitznagel (1992). Only few additional changes concerning JCS took place with the introduction of SGB III, see for example Wunsch (2005).

${ }^{8}$ In 1998 these subsidies were renamed to Structural Adjustment Measures (Strukturanpassungsmaßnahmen).
} 
on the selection of participants. They had a preference for young educated men (Brinkmann and Völkel (1992)).

Participation in a job creation scheme was often financially attractive for unemployed individuals. The wage paid during program participation had to be equal to the wage set by collective wage agreements between the unions and employers organizations for similar but unsubsidized work (Tariflohn). The subsidy given to the employer covered part of (or fully) the wage costs. Participants received a fixed term work contract, which induced regular social security contributions. As a consequence the participant renewed or prolonged his or her eligibility period for unemployment benefits. During participation the local labor office and the participant should continue their search for a regular job. The program ended in case a regular job or a suitable training program was found.

The length of traditional JCS was typically 12 months. In some cases extensions of up to 24 months or even of up to 36 months were possible if a permanent job was offered subsequently by the organizer of JCS. Productive Wage Subsidies East could be granted even longer: up to 48 months in case a permanent job was offered.

The implementation details depended on the type of the subsidy program and the point in time it took place. Formally, participation in traditional JCS required that the person was unemployed for at least 6 months within the last 12 months and entitled to some kind of unemployment payment. The eligibility criteria for Productive Wage Subsidies East were less strict. Besides being eligible for some kind of allowance, a participant needed to have been unemployed for 3 months within the last 12 months, or needed to have had finished a traditional job creation scheme, or enter from short-time work.

The local labor offices could depart from the above mentioned participation criteria. Especially, shortly after the reunification, it was common practice after plant's closure to collectively put the work force of the plant into a so-called Mega-JCS. These programs involved, for example, closing down the obsolete plant or cleaning-up the environmental damage produced by the plant. We do not consider participation in Mega-JCS in our main specification as these programs are not primarily aiming at the integration into regular employment.

This practice and the influence of the large scale ABS-Societies on the selection of participants were the main reasons for the deviations from the target group of traditional JCS. Unemployed older than 50 or younger than 25 and without professional education, long-term unemployed and, as a special regulation for East Germany, also women belonged to the target group. It should be mentioned that for older participants an additional small scale job creation program existed. Albeit being similar to traditional JCS this program solely intended to bridge the time until retirement (Maßnahmen zur Arbeitsbeschaffung für ältere Arbeitslose \$§97-99 EPA). In order to avoid the analysis of pre-retirement effects, we will exclude elderly from our analysis (see Section 3). In the mid 90s, the allocation of JCS became more in line with the predefined target groups.

In April 1997 an additional productive wage subsidies program was implemented: Pro- 
ductive Wage Subsidy for Business Enterprises (Lohnkostenzuschüsse Ost für Wirtschaftsunternehmen, see $\S 249 \mathrm{~h}$ EPA) which was designed to subsidize temporarily regular jobs. This program of ALMP will not be considered here as it might have qualitatively different effects from JCS.

\subsection{Participation and Costs of JCS}

Table 1 shows that the number of program participants peaked in 1992 when 388,000 individuals were employed in traditional JCS in the new federal states (NFS). In this time period high participation rates were mainly realized by Mega-JCS, where the workforce of closing firms were collectively put into a job creation program. Thereafter, policy changes and financial restrictions led to decreasing yearly stocks. Between 1993 and 1997 the stock of participants in traditional JCS fluctuated around 200,000 while the stock of participants in Productive Wage Subsidies East fluctuated around 90,000 per year in East Germany. From 1998 onwards, the number of jobs created via traditional JCS was lower than the number created via Productive Wage Subsidies East. This development was mainly driven by the introduction of the Productive Wage Subsidies for Business Enterprises in April 1997.

Table 1: Participants in JCS (in thousands), 1991-1999

\begin{tabular}{|c|c|c|c|c|c|c|c|c|}
\hline \multirow[t]{2}{*}{ Year } & \multicolumn{3}{|c|}{ Traditional JCS } & \multicolumn{3}{|c|}{$\begin{array}{l}\text { Productive Wage } \\
\text { Subsidies East }\end{array}$} & \multicolumn{2}{|c|}{$\begin{array}{l}\text { Underemployment Rates } \\
\text { in } \%\end{array}$} \\
\hline & NFS & SA & $\frac{S A}{N F S}($ in\% $)$ & NFS & SA & $\frac{S A}{N F S}($ in\% $)$ & NFS & SA \\
\hline 1991 & 208.7 & 35.7 & 17.1 & . & . & . & 25.3 & 24.8 \\
\hline 1992 & 388.1 & 88.0 & 22.7 & . & . & . & 35.3 & 37.3 \\
\hline 1993 & 237.5 & 56.4 & 23.7 & 22.5 & . & . & 32.3 & 34.4 \\
\hline 1994 & 192.5 & 40.0 & 20.8 & 87.7 & 21.0 & 24.0 & 29.4 & 31.8 \\
\hline 1995 & 205.8 & 41.0 & 19.9 & 106.5 & 23.2 & 21.8 & 26.3 & 28.9 \\
\hline 1996 & 191.5 & 40.0 & 20.9 & 86.2 & 17.6 & 20.4 & 25.6 & 28.7 \\
\hline 1997 & 154.5 & 33.0 & 21.4 & 80.1 & 17.1 & 21.4 & 25.1 & 28.8 \\
\hline 1998 & 151.8 & 27.0 & 17.8 & 162.4 & 29.5 & 18.2 & 24.1 & 26.7 \\
\hline 1999 & 168.0 & 30.0 & 17.9 & 180.0 & 29.0 & 16.1 & 22.8 & 26.2 \\
\hline
\end{tabular}

Note: SA: Sachsen-Anhalt, NFS: all new federal states including East Berlin, JCS: Job creation scheme, underemployment $=$ unemployed + short-time workers (full-time) + training participants + JCS participants + early retirement participants

Source: ANBA (Amtliche Nachrichten der Bundesagentur für Arbeit) 1992-2000

The relatively high unemployment rate in Sachsen-Anhalt compared to the other new federal states did not result in a higher share of participants in JCS in the 90s. The number of participants in JCS in Sachsen-Anhalt amounted to $20 \%$ of the total number of participants in all new federal states in the time period considered for both kinds of job creation measures.

Table 2 shows that the expenditures on JCS by the German Federal Employment Agency for both kinds of programs fluctuate around 5 million DM (3.7 billion $€$ in 2015 prices) and reached 
Table 2: Expenditures on JCS by the German Federal Employment Agency (in million DM per year), 1991-1999

\begin{tabular}{cccc}
\hline \hline Year & NFS & SA & $\frac{S A}{N F S}($ in\% $)$ \\
\hline 1991 & 3075 & 612 & 20 \\
1992 & 5083 & 1664 & 33 \\
1993 & 6905 & 1388 & 20 \\
1994 & 4722 & 1680 & 36 \\
1995 & 7109 & 1734 & 24 \\
1996 & 8156 & 1701 & 21 \\
1997 & 6703 & 1422 & 21 \\
1998 & 5453 & 1054 & 19 \\
1999 & 5681 & 1117 & 20 \\
\hline \hline
\end{tabular}

Note: SA: Sachsen-Anhalt, NFS: all new federal states including East Berlin, JCS: Job creation scheme

Source: ANBA (Amtliche Nachrichten der Bundesagentur für Arbeit) 1992-2000

an all-time high in 1996 when costs amounted to more than 8 million DM (6.0 billion $€$ in 2015 prices) in East Germany. In total, JCS counted more than 2.5 million participants and produced expenditures of more than 52 billion DM (39.0 billion $€$ in 2015 prices) in the period 1991-1999 in East Germany.

\section{Data and Descriptive Statistics}

\subsection{Data Set and Sample Selection}

The data used stem from the last three years (1997-1999) of the Labor Market Monitor SachsenAnhalt (LMM-SA). The LMM-SA is a survey of the working-age population living in the new federal state of Sachsen-Anhalt with around 6.000 participants each year. The LMM-SA provides a retrospective monthly employment calendar that goes back until 1990. This observation window includes the introduction of ALMP in East Germany.

The LMM-SA provides individual information on socio-economic characteristics like age and professional education as well as on the labor market status including participation in two categories of ALMP programs: JCS and training. From 1997 onwards, the questionnaire included retrospective questions on the employment status and its monthly changes since 1990. In this way, we obtain complete data on the labor market history of each participant between 1990 and the interview date. Our data source allows us to distinguish the following combined categories of the labor market status on a monthly basis: in education, employed (including full-time employed, part-time employed and self-employed), unemployed, in training, in job creation scheme, and not in active labor force (including military service, pregnancy/maternity 
leave, retirement, etc.). ${ }^{9}$

The sample includes individuals that are between 25 and 50 years old in January 1990 and that had been employed before the Monetary, Economic and Social Union of the Federal Republic of Germany and the GDR went into effect in June 1990. This allows us to analyze the effect of JCS for individuals who belonged to the active labor force of the GDR and who were hence fully affected by the transformation process and subsequent introduction of ALMP programs. Furthermore, we exclude in this way individuals who are close to retirement and might use ALMP programs as a bridge to retirement. Persons that are later on in education, maternity leave or retired are excluded as well as those with missing data on relevant covariates. We define periods of being out of the labor force as unemployment, mainly because being out of the labor force is a rare event for this sample. Table A.1 (in the Appendix) presents an overview of the variables used in this study. Based on these data we construct a sample of inflows into unemployment based on individuals whose labor market history is observable until at least September 1997 without interruption. We consider unemployment spells starting in January 1991 or later only if there exists a prior employment spell of at least one month. ${ }^{10}$

This analysis exploits information on 2,088 individuals who experience at least one unemployment spell between January 1991 and the end of the observation period, which can be September 1997, October 1998 or December 1999. ${ }^{11}$ In total, the data include 3,617 unemployment spells. Thus, several individuals experience multiple spells and the average number of spells per individual amounts to 1.7 (see Table A.3 in the Appendix). Transitions to other destinations than to employment are treated as right censored. Thus, if an individual enters an alternative ALMP program like training before finding regular employment, the spell is also considered as censored at the point in time the individual enters the alternative program. We additionally estimate specifications in which we define periods of training participation as unemployment and models in which we consider participation in training programs as an alternative treatment. For these specifications, unemployment continues during training participation. Moreover, unemployment spells are right censored in case the observation period ends before an exit out of unemployment can be observed.

In case of treatment, we observe the exact moment of the entry into the program and the actual program duration. However, we do not have any information on the planned participation duration in a job creation scheme. In our model specifications, the time spent in a job creation scheme is assumed to contribute to the unemployment duration. Although program participants may search for a job with reduced effort, they still do search, hence they should be treated as unemployed.

The phrase job creation schemes, JCS includes all variants of public employment programs, although they are conceptually different, as mentioned in Section 2.2. As it is unclear whether

\footnotetext{
${ }^{9}$ For more details on the data set see Bergemann, Fitzenberger, and Speckesser (2009).

${ }^{10}$ Due to data restrictions on the local unemployment rates that are included as controls in the analysis, we have to exclude unemployment spells starting before January 1991.

${ }^{11} \mathrm{We}$ consider persons as unemployed if they indicated to be in a training program for 1 month.
} 
programs starting after April 1997 are JCS or productive wage subsidies for regular jobs, we will only use information on program participation that started before April 1997 and treat entries after April 1997 as right censored. The baseline specification of the analysis excludes participants in Mega-JCS, identified as those individuals who enter the program directly after employment. We find a high concentration of Mega-JCS in Sachsen-Anhalt in the early 90s. In 180 cases a direct transition from employment to a job creation scheme can be observed. In a sensitivity analysis we are going to investigate the effects of both traditional and Mega-JCS.

\subsection{Labor Market Transitions and Durations}

We observe that around $11 \%$ of the unemployment spells include a period of participation in a job creation scheme (see Table A.2 in the Appendix). About half of the spells without treatment and $30 \%$ of the spells with treatment end in a transition into regular employment. $27 \%$ of the unemployment spells that are observed to include participation in a job creation scheme are followed by a period of participation in a training program while for $30 \%$ no transition can be observed within the observation period.

Figures 2 and 3 present non-parametric Kaplan-Meier estimates of the hazard rates based on information of the first unemployment spell. Figure 2 contains the empirical exit rate from unemployment into employment which is highest at the beginning of the unemployment spell and then starts to decline. After a second peak at an unemployment duration of 12 months which could be caused by the expiration of unemployment benefits, the exit rate circulates around $1.5 \%$. The conditional probability of entering JCS increases to a level of around $2.5 \%$ after one year of unemployment. In the subsequent period the hazard rate fluctuates around a level of $1.0 \%$. Figure 3 shows the empirical exit rate from the program to unemployment and employment, respectively. Both plots reveal strong peaks at 12 and 24 months indicating that a substantial share of participants re-enters unemployment and some participants enter employment directly after the program has expired. ${ }^{12}$

A job creation scheme typically lasts 12 months. Figure 4 shows that around $40 \%$ of all JCS end after one year and only a few last longer than 24 months. The peaks at 12 and 24 months indicate that many individuals exploit the program to the full extent which can be interpreted as a sign of locking-in effects.

\footnotetext{
${ }^{12}$ Table A.3 in the Appendix presents summary statistics of the duration of unemployment, of subsequent employment and of JCS separately for complete and right censored spells. Some individuals repeatedly enter JCS during one unemployment spell. In this case we calculate several uninterrupted durations of program participation. The average number of treatments per treated unemployment spell amounts to 1.2, whereas the maximal number is 3 .
} 

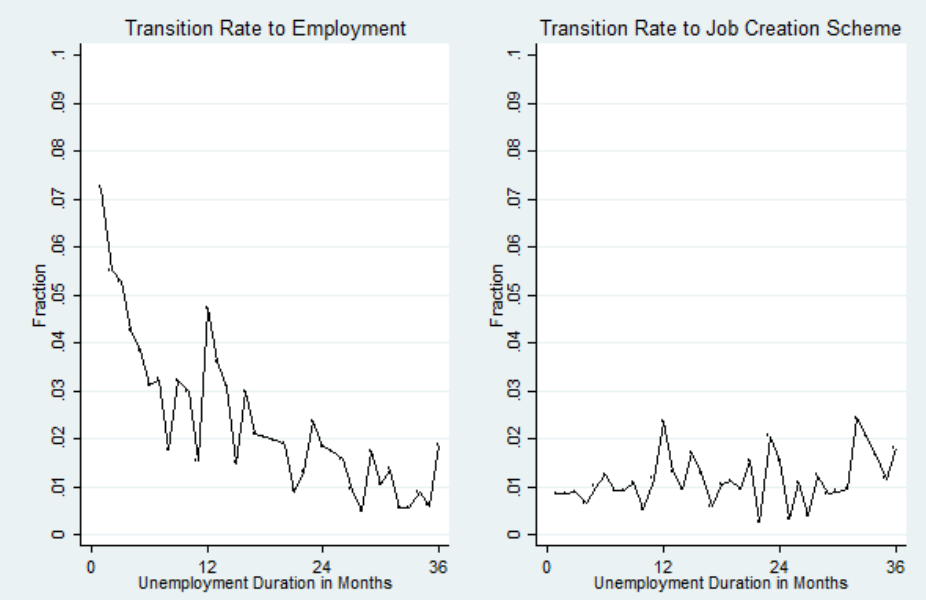

Note: Empirical exit rates are based on the first unemployment spell
Source: LMM-SA, 1997-1999, own computations

Figure 3: Transition from Job Creation Scheme to (Un)employment
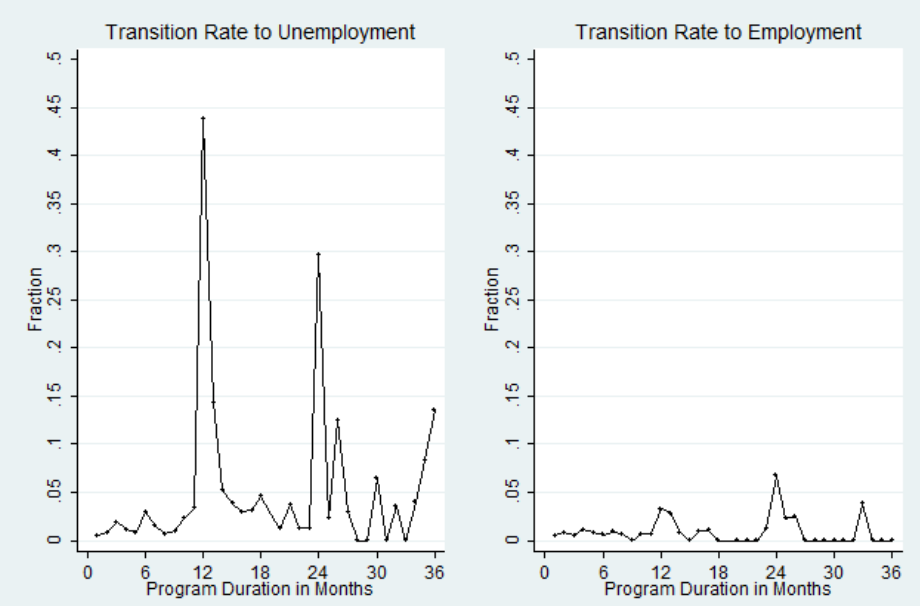

Note: Empirical exit rates gre based on the first unemployment spell
Source: LMM-SA, 1997-1999, own computations

\subsection{Descriptive Statistics of Observable Characteristics}

Table 3 shows descriptive statistics of the observed covariates for all individuals and separately for program participants and nonparticipants. The values of these variables are constant over the observation period. They are measured at the date of the interview with the exception of age which refers to the year 1990 .

About half of the unemployed in our sample are women. $57 \%$ of the unemployed that participate in a job creation scheme during their first unemployment spell are female. In total, the largest fraction of unemployed individuals is between 45 and 50 years old in 1990. One third of the program participants are 45 to 50 years old.

Furthermore, we include a set of dummy variables indicating the professional education of the unemployed. The comparatively small number of individuals without or with partly vocational training arises from the obligation to perform a vocational training (Berufsbil- 
Figure 4: Distribution of Program Duration

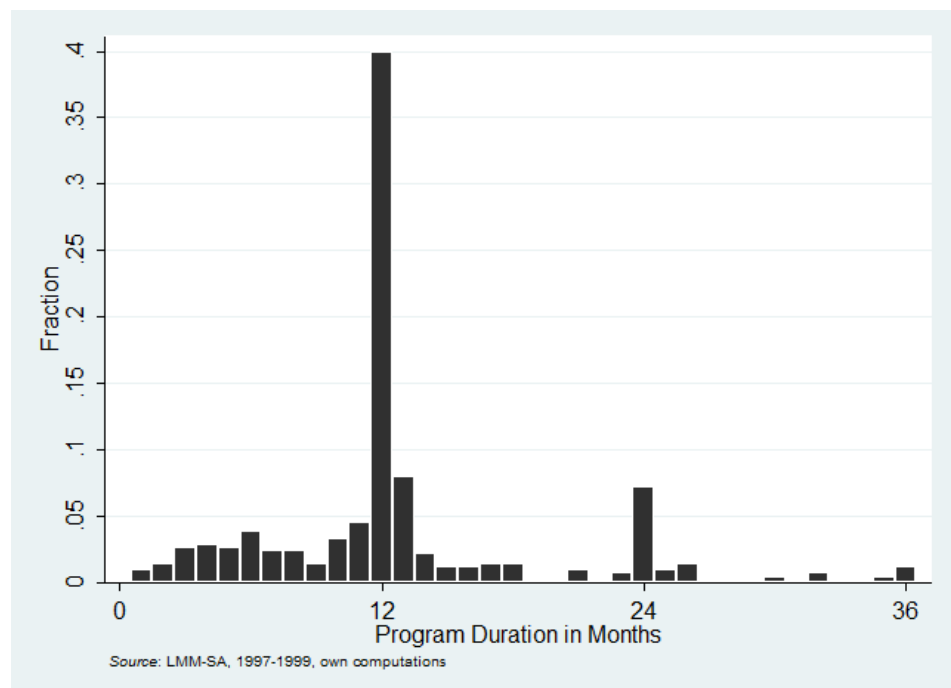

Table 3: Descriptive Statistics of Covariates in \%

\begin{tabular}{lccc}
\hline \hline & All & Participants & Nonparticipants \\
\hline Ages 25-29 & 16.2 & 9.9 & 17.1 \\
Ages 30-34 & 19.7 & 20.2 & 19.6 \\
Ages 35-39 & 22.2 & 18.6 & 22.7 \\
Ages 40-44 & 16.5 & 17.5 & 16.3 \\
Ages 45-50 & 25.4 & 33.8 & 24.2 \\
Female & 50.4 & 57.4 & 49.4 \\
Male & 49.6 & 42.6 & 50.6 \\
No Vocational Training & 1.7 & 3.0 & 1.5 \\
Partly Vocational Training & 2.1 & 2.7 & 2.0 \\
Vocational Training & 50.8 & 50.2 & 50.8 \\
Advanced Vocational Training & 7.4 & 5.3 & 7.7 \\
Technical College & 16.0 & 16.3 & 15.9 \\
University Degree & 22.0 & 22.4 & 22.0 \\
\hline Total & $\mathbf{2 , 0 8 8}$ & $\mathbf{2 6 3}$ & $\mathbf{1 , 8 2 5}$ \\
\hline \hline
\end{tabular}

Note: Descriptive statistics are based on the first unemployment spell.

Source: LMM-SA, 1997-1999, own computations 
dungspflicht) in the former GDR. Table 3 shows that about half of the unemployed individuals experience a vocational training and one-fifth exhibit a university degree. The share of unemployed with a high professional education is slightly higher for participants than for nonparticipants.

In addition, the list of covariates included in our estimations contains year and quarter dummies, regional dummies, monthly unemployment rates by labor market district, and a time-varying variable capturing the distance from the expiration date of unemployment benefit claims. $^{13}$

\section{Empirical Model}

We are interested in the causal impact of entering a job creation scheme on the unemployment duration and subsequent employment stability. Individuals are defined to be treated if they enter a job creation scheme in month $t$ of the unemployment spell from the corresponding month $t$ onwards. In this section we start with the presentation of a bivariate duration model for the duration until leaving unemployment for a job and the duration until the treatment following the timing-of-events approach (Abbring and van den Berg, 2003). We have monthly information about different employment states and estimate discrete time duration models. Abbring and van den Berg (2003) provide a proof for continuous time models. For identification in dynamic discrete models see Heckman and Navarro (2007). In a second step we investigate the subsequent employment stability of program participants and nonparticipants by introducing a third transition process similar to van den Berg and Vikström (2014). In addition to that we estimate models allowing for a random treatment effect similar to Richardson and van den Berg (2013) and models with two treatments (JCS and training), whereby we allow the probability of entering one treatment to depend on the participation in another treatment. None of these model extensions leads to different results. Therefore, we focus in the following on the description of our main econometric model.

Our data set contains multiple unemployment spells for some individuals, which facilitates identification and estimation of the joint distribution of the unobserved heterogeneity variables (Honoré 1993). Moreover, our data set includes time-varying variables such as the local unemployment rate which provide a more robust source of identification than time-invariant covariates (Gaure, Røed and Zhang 2007).

\subsection{Durations until employment and until treatment}

The transition probability of leaving unemployment for a job $\theta_{u}(t)$ and the probability of entering a job creation scheme $\theta_{p}(t)$ are assumed to vary with observed characteristics $x_{t}$, the

\footnotetext{
${ }^{13}$ The unemployment rates are corrected for the number of participants in ALMP programs and hence are larger than the official numbers.
} 
unobserved heterogeneity terms $v_{u}$ and $v_{p}$, respectively and the elapsed unemployment duration $t$. Additionally, the probability of leaving unemployment depends on the treatment status in period $t$. We assume that the unobserved heterogeneity is constant over time, i.e. across repeated spells of unemployed individuals, and uncorrelated with observed characteristics. $\theta_{u}(t)$ and $\theta_{p}(t)$ can be expressed by complementary log log specifications:

$$
\begin{aligned}
\theta_{u}\left(t \mid x_{t}^{\prime}, v_{u}, t_{p}\right) & =1-\exp \left(-\exp \left(\lambda_{u}(t)+x_{t}^{\prime} \beta_{u}+\mathbf{1}\left(t \geq t_{p}\right) \boldsymbol{\delta}_{u}+v_{u}\right)\right. \\
\theta_{p}\left(t \mid x_{t}^{\prime}, v_{p}\right) & =1-\exp \left(-\exp \left(\lambda_{p}(t)+x_{t}^{\prime} \beta_{p}+v_{p}\right)\right)
\end{aligned}
$$

$\lambda_{u}(t)$ and $\lambda_{p}(t)$ capture the duration dependencies and the vectors $\beta_{u}$ and $\beta_{p}$ capture the influence of observed covariates. $\delta_{u}$ corresponds to the effect of being treated on the probability of finding a job. The treatment effect might vary depending on the time since the treatment. In our baseline model, we allow for a time-varying treatment effect by specifying two intervals following the start of the treatment in period $t_{p}:\left(t_{p} \leq t \leq t_{p}+c_{1}\right)$ and $\left(t>t_{p}+c_{1}\right)$. The hazard rate is shifted by $\delta_{u_{1}}$ in the first $c_{1}$ months after program start. After a program duration of $c_{1}$ months, the hazard rate is shifted again by $\delta_{u_{2}}$. We additionally estimate models with more than two time intervals for the treatment effect, models allowing for effect heterogeneity with respect to selected observed characteristics, and models with treatment effects depending on the point in time the treatment starts.

For identification it is - similar to alternative micro-econometric approaches like matching - important that the unemployed job seekers do not anticipate the exact moment a JCS starts. This no-anticipation assumption implies that the treatment does not affect the probability of leaving unemployment for a job before the moment the treatment starts. ${ }^{14}$ It is likely that this assumption holds in our context. As discussed in Subsection 2.3, the case worker decides about participation. He has to place his candidates as early as possible and has to check potential alternative job offers. Moreover, the gap between program admission and actual start of the program is rather small. Surveys among caseworkers indicate that on average the time span between application and program start was three months (Völkel 1994). One important determinant of the program participation might be the expiration date of benefit entitlements, since benefit claims can be prolonged by participation in a job creation scheme. We are able to account for this mechanism by constructing a variable capturing the distance until the individual expiration date.

\footnotetext{
${ }^{14}$ It is important to note that the no-anticipation assumption does not exclude that individuals know the probability distribution of future events conditional on observable and unobservable characteristics. Individuals may change their optimal behavior to determinants of the treatment process, but not to the realizations of future treatments.
} 


\subsection{Employment stability}

We additionally investigate the impact of the treatment on the subsequent employment stability. The transition probability from employment to unemployment $\theta_{e}(t)$ can be expressed by:

$$
\theta_{e}\left(t \mid x, v_{e}, t_{u}, t_{p}\right)=1-\exp \left(-\exp \left(\lambda_{e}(t)+x_{t}^{\prime} \beta_{e}+\mathbf{1}\left(t_{u} \geq t_{p}\right) \delta_{e}+\sum_{d=2}^{k} \gamma_{d} I_{u}\left(t_{u}\right)+v_{e}\right)\right)
$$

$\lambda_{e}(t)$ captures the duration dependence in employment. The probability of reentering unemployment depends on observed characteristics $x_{t}$, unobserved heterogeneity $v_{e}$, and on the realized unemployment duration in a flexible way by a series of dummy variables. The unobserved characteristics are allowed to be correlated with the unobserved factors $v_{p}$ and $v_{u}$. The treatment effect $\delta_{e}$ captures the impact of program participation during the previous unemployment spell.

\subsection{Distribution of unobserved heterogeneity and likelihood function}

We specify the joint distribution $G$ of the unobserved heterogeneity terms $v_{u}, v_{p}$ and $v_{e}$ to be discrete with a $M$ support points. The associated probabilities are given by:

$$
\operatorname{Pr}\left(v_{u}=v_{u}^{m}, v_{p}=v_{p}^{m}, v_{e}=v_{e}^{m}\right)=p_{m}, \text { for } m=1, \ldots, M
$$

To force the class probabilities to be between zero and one and to sum up to one, we use a multinomial logit parameterization of the class probabilities

$$
p_{m}=\frac{\exp \left(\omega_{m}\right)}{\exp \left(\sum_{m=1}^{M} \omega_{m}\right)} \text { with } \omega_{1}=0, \text { for } m=1, \ldots, M \text {. }
$$

For a model with $M=2, G$ would be described by 4 parameters, for $M=3$ we estimate 8 parameters, etc. This approach allows for a flexible covariance matrix for the unobserved heterogeneity. For similar strategies for modeling the unobserved heterogeneity see for example Aitkin (1999), Crépon, Ferracci, Jolivet, and Van den Berg (2010) and Caliendo, Künn, and Uhlendorff (2016). Our model selection with respect to the number of mass points is based on the bivariate duration model. We increase the number of mass points until we cannot improve the model fit anymore. The evaluation of the model fit is based on the Akaike Criterion (AIC). The likelihood contribution of individual $i$ for given $v_{u}^{m}, v_{p}^{m}, v_{e}^{m}$ in period $t$ can be expressed by 
$l_{i t}\left(x_{i t}, v_{u}^{m}, v_{p}^{m}, v_{e}^{m}\right)$ and the log likelihood for the sample with $N$ individuals is given by: ${ }^{15}$

$$
\ln L=\sum_{i=1}^{N} \ln \left(\sum_{m=1}^{M} p_{m} \prod_{t=1}^{T}\left[l_{i t} \mid x_{i t}, v_{u}^{m}, v_{p}^{m}, v_{e}^{m}\right]\right)
$$

\section{Results}

We start with presenting the results based on a bivariate duration model consisting of the duration until entry into job creation scheme and the duration until entry into employment. In the baseline specification, we specify a treatment effect for the first 11 months and for the period from 12 months onwards after the start of the JCS. The choice of this cut-off value is motivated by the typical program duration of 12 months and allows us to investigate potential locking-in effects.

In a second step we introduce effect heterogeneity with respect to the point in time the treatment starts, the elapsed treatment duration and selected observed characteristics. In a third step we present results for a model with three equations: the transition rate from unemployment into the program, from unemployment into employment and from employment back into unemployment. Fourth, we estimate models with a second treatment, the participation in training programs. Finally we allow for effect heterogeneity with respect to unobserved heterogeneity (random treatment effects) and investigate the sensitivity of our results with respect to different choices about the definition of the sample and the unemployment state.

\subsection{Baseline Results}

We start with a discussion of the model selection in terms of the number of mass points for the heterogeneity components. This selection is based on a comparison of the model fit. We increase successively the number of mass points until we cannot improve the model fit, evaluated on basis of the Akaike Information Criterion (AIC) and the Bayesian Information Criterion (BIC), anymore. In our application, the smallest value of the AIC and the BIC is reached in the specification with three unobserved mass points (see Table B.1 in the Appendix). In comparison to the model without unobserved heterogeneity, we estimate in this specification six additional parameters for the distribution of unobserved heterogeneity. ${ }^{16}$ For the different transition processes we choose a flexible specification of the duration dependence based on eight time intervals.

\footnotetext{
${ }^{15}$ For the models allowing for random treatment effects we introduce an additional unobserved term $v_{j c s}^{m}$. For models taking a second treatment (training participation) into account the model is extend by an additional transition rate from unemployment to training, which depends on the unobserved term $v_{t}^{m}$.

${ }^{16}$ Figure B.1 in the Appendix presents the empirical exit rate from unemployment to work during the first unemployment spell jointly for program participants and nonparticipants and additionally the predicted monthly transition rates based on the estimated parameters. The predicted hazard rate fits well with the average of the empirical hazard rate and does a good job of describing the duration dependence.
} 
In Table 4 we present the parameter estimates for the baseline model. Considering the unobserved heterogeneity distribution, we find that individuals with a higher unemployment exit rate tend to have a lower program participation rate. The correlation between the unobserved heterogeneity terms $v_{p}$ and $v_{u}$ is -0.51 . This suggests that ignoring the selection based on unobserved heterogeneity would lead to biased estimates.

The main parameters of interest are the treatment effects of entering a job creation scheme depending on the time since program start. In the first 11 months since start of the program, the estimated coefficient is with -1.17 negative and significant. This effect states that the transition rate to employment is reduced by $69 \%(\exp (-1.17)-1)$ in the first 11 months after start of participation. From month 12 after program onwards, the treatment effect vanishes. This result indicates that locking-in effects seem to be important. During program participation, the job finding probability is significantly reduced and after a typical program duration of 12 months the effect becomes positive but insignificant.

\subsection{Heterogeneous Treatment Effects}

We start with considering a more flexible time-varying specification of the treatment effect. In line with the typical program durations of 12 and 24 months and inspired by the peaks in the transition rate from the program participation into employment (see Figure 3), we allow for five different treatment effects dependent on the elapsed treatment duration. $\delta_{u_{1}}$ measures the effect of JCS for the period $t_{p} \leq t \leq t_{p}+11, \delta_{u_{2}}$ for the period $t_{p}+11<t \leq t_{p}+13, \delta_{u_{3}}$ for the period $t_{p}+13<t \leq t_{p}+23, \delta_{u_{4}}$ for the period $t_{p}+23<t \leq t_{p}+25$ and finally $\delta_{u_{5}}$ for the period $t>t_{p}+25$.

Very similar to the baseline model, the estimated treatment effects indicate that the hazard rate is significantly lower by $69 \%$ in the first 11 months after start of participation (Panel A in Table 5). In month 12 and 13, the point estimate is positive but insignificant, followed by an estimated effect close to zero in months 14 to 23 after program start. The hazard rate increases significantly by $240 \% 24$ to 25 months after entering a job creation scheme. After 25 months, the effect is still positive but not statistically significant. These results confirm the presence of locking-in effects: individuals have a significantly reduced job finding probability during participation. The treatment effect becomes positive and partly significant after the job creation scheme has finished, which is typically after 12 or 24 months. However, this positive impact on the transition rate to work is not long-lasting.

In an alternative specification, we estimate treatment effects depending on whether program entry occurs in the years 1991-1992, 1993-1994 or in 1995-1997. The results in Table 5 Panel B show that the effects of participating in a JCS are stable over time.

We additionally allow the treatment effect to depend on the elapsed unemployment duration at the moment of the program entry. Table 5 Panel $\mathrm{C}$ presents the corresponding treatment effects. The point estimates indicate strong locking-in effects independent of the elapsed unem- 
Table 4: Baseline Estimation Results

\begin{tabular}{|c|c|c|c|c|}
\hline \multirow{4}{*}{$\begin{array}{l}\text { Effect of JCS in months } 1 \text { - } 11 \text { after program start } \\
\text { Effect of JCS in months }>11 \text { after program start } \\
\text { Unobserved heterogeneity: }\end{array}$} & \multicolumn{2}{|c|}{$\begin{array}{l}\text { Transition } \\
\qquad U \rightarrow E\end{array}$} & \multicolumn{2}{|c|}{$\begin{array}{l}\text { Transition } \\
U \rightarrow J C S\end{array}$} \\
\hline & $-1.171^{* * *}$ & $(0.21)$ & & \\
\hline & 0.198 & $(0.23)$ & & \\
\hline & & & & \\
\hline$v_{1}$ & $-3.731^{* * *}$ & $(0.80)$ & $-7.997^{* * *}$ & $(1.42)$ \\
\hline$v_{2}-v_{1}$ & $1.808^{* * *}$ & $(0.20)$ & $-0.615^{* *}$ & $(0.29)$ \\
\hline$v_{3}-v_{1}$ & $3.421^{* * *}$ & $(0.26)$ & -0.261 & $(0.36)$ \\
\hline$\omega_{2}$ & $0.500^{*}$ & $(0.26)$ & & \\
\hline$\omega_{3}$ & $-0.444^{*}$ & $(0.25)$ & & \\
\hline$p_{2}$ & 0.501 & & & \\
\hline$p_{3}$ & 0.195 & & & \\
\hline $\operatorname{corr}\left(v_{u e}, v_{u p}\right)$ & -0.509 & & & \\
\hline \multicolumn{5}{|l|}{ Duration dependence: } \\
\hline 4-6 month & 0.046 & $(0.08)$ & 0.218 & $(0.20)$ \\
\hline 7-9 month & -0.038 & $(0.10)$ & $0.501^{* *}$ & $(0.23)$ \\
\hline 10-12 month & -0.033 & $(0.12)$ & $0.891^{* * *}$ & $(0.24)$ \\
\hline 13-18 month & -0.051 & $(0.13)$ & $0.678^{* * *}$ & $(0.26)$ \\
\hline 19-24 month & $-0.351^{* *}$ & $(0.17)$ & 0.495 & $(0.31)$ \\
\hline 25-36 month & $-0.442^{* *}$ & $(0.20)$ & 0.290 & $(0.31)$ \\
\hline$>36$ month & $-0.715^{* * *}$ & $(0.24)$ & -0.639 & $(0.41)$ \\
\hline \multicolumn{5}{|l|}{ Individual characteristics: } \\
\hline Ages $30-34$ & 0.086 & $(0.18)$ & 0.567 & $(0.41)$ \\
\hline Ages 35-39 & 0.107 & $(0.19)$ & $0.876^{* *}$ & $(0.41)$ \\
\hline Ages $40-44$ & -0.091 & $(0.19)$ & $0.759^{*}$ & $(0.41)$ \\
\hline Ages $45-50$ & $-0.360^{*}$ & $(0.20)$ & $1.022^{* *}$ & $(0.42)$ \\
\hline Ages $>50$ & $-1.137^{* * *}$ & $(0.22)$ & $1.306^{* * *}$ & $(0.43)$ \\
\hline Female & $-1.139^{* * *}$ & $(0.09)$ & -0.027 & $(0.12)$ \\
\hline Partly Vocational Training & $-1.149^{* * *}$ & $(0.37)$ & -0.162 & $(0.50)$ \\
\hline Vocational Training & $0.475^{* *}$ & $(0.24)$ & 0.139 & $(0.36)$ \\
\hline Advanced Vocational Training & 0.387 & $(0.28)$ & 0.110 & $(0.43)$ \\
\hline Technical College & 0.386 & $(0.25)$ & 0.276 & $(0.38)$ \\
\hline University Degree & $0.593^{* *}$ & $(0.25)$ & 0.557 & $(0.38)$ \\
\hline \multicolumn{5}{|l|}{ Regions: } \\
\hline Dessau & 0.263 & $(0.22)$ & -0.301 & $(0.24)$ \\
\hline Halberstadt & 0.053 & $(0.24)$ & -0.418 & $(0.27)$ \\
\hline Halle & $0.540^{* *}$ & $(0.22)$ & $-1.144^{* * *}$ & $(0.32)$ \\
\hline Magdeburg & 0.322 & $(0.21)$ & -0.218 & $(0.22)$ \\
\hline Merseburg & 0.319 & $(0.22)$ & -0.242 & $(0.24)$ \\
\hline Sangerhausen & 0.137 & $(0.24)$ & 0.290 & $(0.28)$ \\
\hline Stendal & 0.372 & $(0.23)$ & -0.425 & $(0.27)$ \\
\hline Dummy for remaining unemployment benefit claims & -0.153 & $(0.12)$ & $-0.863^{* * *}$ & $(0.24)$ \\
\hline Remaining unemployment benefit claims & $-0.042^{* *}$ & $(0.02)$ & 0.037 & $(0.04)$ \\
\hline Remaining unemployment benefit claims squared & 0.001 & $(0.00)$ & -0.001 & $(0.00)$ \\
\hline Unemployment rate & -0.081 & $(0.05)$ & 0.015 & $(0.09)$ \\
\hline Unemployment rate squared & 0.002 & $(0.00)$ & -0.001 & $(0.00)$ \\
\hline $\mathrm{N}$ & \multicolumn{4}{|c|}{2,088} \\
\hline
\end{tabular}

Note: Standard errors are in parentheses, current year and quarter dummies are not reported, coefficients are statistically significant at the ${ }^{*} 10 \%,{ }^{* *} 5 \%$ and ${ }^{* * *} 1 \%$ level, JCS: Job creation schemes, U: Unemployment, E: Employment

Source: LMM-SA, 1997-1999, own computations 
Table 5: Time Dependent Effect of JCS

\begin{tabular}{|c|c|c|}
\hline & Coefficient & Standard Error \\
\hline \multicolumn{3}{|c|}{ Panel A. Effect of JCS Dependent on Time Since Program Start } \\
\hline Effect of JCS in months 1 - 11 after program start & $-1.169^{* * *}$ & $(0.21)$ \\
\hline Effect of JCS in months 12 - 13 after program start & 0.340 & $(0.32)$ \\
\hline Effect of JCS in months 14 - 23 after program start & -0.046 & $(0.26)$ \\
\hline Effect of JCS in months 24 - 25 after program start & $1.225^{* * *}$ & $(0.39)$ \\
\hline Effect of JCS in months $>25$ after program start & 0.245 & $(0.35)$ \\
\hline \multicolumn{3}{|c|}{ Panel B. Effect of JCS Dependent on Year of Program Start } \\
\hline Effect of JCS in months $1-11$ after program start & $-1.139^{* * *}$ & $(0.34)$ \\
\hline $\begin{array}{l}\text { Effect of JCS in months }>11 \text { after program start } \\
\text { Start occurs in year } 1993 \text { or } 1994\end{array}$ & 0.208 & $(0.32)$ \\
\hline Effect of JCS in months 1 - 11 after program start & $-1.032^{* * *}$ & $(0.35)$ \\
\hline $\begin{array}{l}\text { Effect of JCS in months }>11 \text { after program start } \\
\text { Start occurs in year } 1995 \text { or } 1996 \text { or } 1997\end{array}$ & 0.187 & $(0.31)$ \\
\hline Effect of JCS in months $1-11$ after program start & $-1.360^{* * *}$ & $(0.37)$ \\
\hline Effect of JCS in months $>11$ after program start & 0.201 & $(0.29)$ \\
\hline
\end{tabular}

Panel C. Effect of JCS Dependent on Elapsed Unemployment Duration at Time of Program Start

Start occurs in the first 5 months of unemployment

Effect of JCS in months 1 - 11 after program start

Effect of JCS in months $>11$ after program start

$-1.116^{* * *}$

0.120

Start occurs in the months 6 - 10 of unemployment

Effect of JCS in months 1 - 11 after program start

$-1.199^{* * *}$

Effect of JCS in months $>11$ after program start

$-0.401$

Start occurs in the months $11-13$ of unemployment

Effect of JCS in months 1 - 11 after program start

$-1.096^{* *}$

0.117

Effect of JCS in months $>11$ after program start

$-1.807^{* * *}$

Start occurs in the months $14-24$ of unemployment

Effect of JCS in months 1 - 11 after program start

0.478

Effect of JCS in months $>11$ after program start

Start occurs in more than 24 months of unemployment

Effect of JCS in months 1 - 11 after program start

$-1.096$

Effect of JCS in months $>11$ after program start

$1.062^{* * *}$

Note: Standard errors are in parentheses, current year and quarter dummies are not reported, coefficients are statistically significant at the ${ }^{*} 10 \%,{ }^{* *} 5 \%$ and ${ }^{* * *} 1 \%$ level

Source: LMM-SA, 1997-1999, own computations 
ployment duration. These effects are especially strong for participants who enter a job creation scheme in month 14-24 of their unemployment spell. Unemployed who start participating after 24 months of unemployment seem to benefit from participation: after a treatment duration of 11 months, they are significantly more likely to find a job compared to nonparticipants.

Table 6: Effect of JCS Dependent on Observed Characteristics

\begin{tabular}{llc}
\hline \hline & Coefficient & Standard Error \\
\hline Effect of JCS in months $1-11$ after program start & $-1.708^{* * *}$ & $(0.33)$ \\
Effect of JCS in months $>11$ after program start & -0.257 & $(0.34)$ \\
Effect of JCS $\quad \times$ Female & $0.596^{* *}$ & $(0.26)$ \\
Effect of JCS $\quad \times$ Age $>$ 45 & -0.218 & $(0.26)$ \\
Effect of JCS $\quad \times$ High skilled & $0.713^{* * *}$ & $(0.25)$ \\
\hline \hline
\end{tabular}

Note: Standard errors are in parentheses, current year and quarter dummies are not reported, coefficients are statistically significant at the ${ }^{*} 10 \%,{ }^{* *} 5 \%$ and ${ }^{* * *} 1 \%$ level, JCS: Job creation schemes

Source: LMM-SA, 1997-1999, own computations

In a next step we investigate effect heterogeneity with respect to selected observed characteristics. We estimate the treatment effect in the first 11 months after start of the job creation scheme and the subsequent period and allow for a common shift of both treatment effects depending on the age, the gender and the skill level. For women and high skilled participants we find a significantly positive treatment effect indicating that these individuals seem to suffer less from locking-in effects and are more likely to find a job after a typical program duration of 12 months than male and low/medium skilled participants (see Table 6). We find no evidence for effect heterogeneity with respect to the age of the participants. A joint test suggests that the effect of JCS in the first 11 months is insignificant while the effect 11 months after the start of the program becomes significantly positive for high skilled women. We additionally estimate a model allowing for an interaction effect of being high skilled and being a female. The results are reported in Table B.2 and joint tests based on this specification lead to similar conclusions. High skilled women seem to benefit from the participation in JCS, while JCS increases the unemployment duration especially for low- and medium-skilled men.

\subsection{Subsequent Employment Stability}

In this section we report estimation results based on a model with three transition rates: the transition rate from unemployment to employment, from unemployment into the program and from employment back to unemployment. Table 7 presents the estimation results for the baseline specification. The estimated treatment effects on the exit rate to work are quite similar to the results we obtain with the baseline specification with two transition rates. We do not find any evidence for an impact on the employment stability. These findings do not change in any 
of the above mentioned specifications. ${ }^{17}$ This suggests that the job quality - measured by the probability of reentering unemployment - does not depend on participation in JCS.

Table 7: Effect of JCS for Model with Three Transition Rates

\begin{tabular}{lllll}
\hline \hline & \multicolumn{2}{c}{ Transition } & \multicolumn{2}{c}{ Transition } \\
& \multicolumn{2}{c}{$U \rightarrow E$} & & \multicolumn{2}{c}{$E \rightarrow U$} \\
\hline & Coef. & S.E. & Coef. & S.E. \\
\hline Effect of JCS in months 1 - 11 after program start & $-1.144^{* * *}$ & $(0.21)$ & 0.354 & $(0.25)$ \\
Effect of JCS in months $>11$ after program start & 0.202 & $(0.21)$ & 0.080 & $(0.28)$ \\
\hline \hline
\end{tabular}

Note: Standard errors (S.E.) are in parentheses, coefficients are statistically significant at the ${ }^{*} 10 \%,{ }^{* *} 5 \%$ and ${ }^{* * *}$ 1\% level, JCS: Job creation schemes, U: Unemployment, E: Employment

Source: LMM-SA, 1997-1999, own computations

\subsection{Multiple Treatment Effects}

In this subsection we present estimation results of a model specification which allows for multiple treatment effects: we investigate the impacts of two treatments, participation in a job creation scheme and participation in training. To be precise, we estimate three transition rates: the transition rate from unemployment to employment, the transition rate from unemployment to JCS and the transition rate from unemployment to training. We allow for correlations between these three transition processes. With this specification we are able to test whether our previous results change when we take into account that some unemployed might participate in a training program before or after participation in a job creation scheme. Our data suggests that $7 \%$ of all unemployment spells include treatment only in terms of participation in JCS and 19\% only in terms of participation in training. For $3 \%$ of all unemployment spells we observe a participation in a job creation scheme followed by a period of training and $3 \%$ had a period of training before entering a job creation scheme.

Table 8 presents the estimation results for this model. Panel A shows the results for a specification where we only allow for a direct treatment effect of training and JCS, separately in the first 11 months and in more than 11 months after start of participation, for the transition rate from unemployment to employment. Panel B presents the results for a specification where we allow for a direct treatment effect of training (JCS), separately in the first 11 months and in more than 11 months after start of participation, for the transition rate from unemployment to employment and for the transition rate from unemployment into JCS (training). Our findings indicate that our estimated effects of participating in a job creation scheme do not change when taking participation in training into account. For both programs we observe a reduced impact on the probability of entering the other program during the first 11 months after program start. For

\footnotetext{
${ }^{17}$ Results of the models with effect heterogeneity are reported in the Appendix (see Tables B.3 and B.4).
} 
the training program, we observe an increased probability for entering the job creation scheme after this period. Moreover, the training program seems to have first a negative and after some time a significantly positive impact on the transition rate to work. ${ }^{18}$

Table 8: Multiple Treatment Effects

\begin{tabular}{|c|c|c|c|c|c|c|}
\hline & \multicolumn{2}{|c|}{$\begin{array}{l}\text { Transition } \\
\quad U \rightarrow E\end{array}$} & \multicolumn{2}{|c|}{$\begin{array}{l}\text { Transition } \\
U \rightarrow J C S\end{array}$} & \multicolumn{2}{|c|}{$\begin{array}{c}\text { Transition } \\
U \rightarrow \text { Training }\end{array}$} \\
\hline & Coef. & S.E. & Coef. & S.E. & Coef. & S.E. \\
\hline \multicolumn{7}{|l|}{ Panel A. Specification 1} \\
\hline $\begin{array}{l}\text { Effect of JCS in months } 1-11 \\
\text { after program start }\end{array}$ & $-1.071^{* * *}$ & $(0.20)$ & & & & \\
\hline $\begin{array}{l}\text { Effect of JCS in months }>11 \\
\text { after program start }\end{array}$ & 0.056 & $(0.18)$ & & & & \\
\hline $\begin{array}{l}\text { Effect of Training in months } 1-11 \\
\text { after program start }\end{array}$ & $-0.629^{* * *}$ & $(0.14)$ & & & & \\
\hline $\begin{array}{l}\text { Effect of Training in months }>11 \\
\text { after program start }\end{array}$ & $0.839^{* * *}$ & $(0.15)$ & & & & \\
\hline \multicolumn{7}{|l|}{ Panel B. Specification 2} \\
\hline $\begin{array}{l}\text { Effect of JCS in months } 1-11 \\
\text { after program start }\end{array}$ & $-1.163^{* * *}$ & $(0.20)$ & & & $-2.034^{* * *}$ & $(0.37)$ \\
\hline $\begin{array}{l}\text { Effect of JCS in months }>11 \\
\text { after program start }\end{array}$ & 0.014 & $(0.20)$ & & & 0.228 & $(0.19)$ \\
\hline $\begin{array}{l}\text { Effect of Training in months } 1-11 \\
\text { after program start }\end{array}$ & $-0.726^{* * *}$ & $(0.15)$ & $-2.130^{* * *}$ & $(0.41)$ & & \\
\hline $\begin{array}{l}\text { Effect of Training in months }>11 \\
\text { after program start }\end{array}$ & $0.712^{* * *}$ & $(0.16)$ & $0.397^{* *}$ & $(0.20)$ & & \\
\hline
\end{tabular}

Note: Standard errors (S.E.) are in parentheses, coefficients are statistically significant at the ${ }^{*} 10 \%,{ }^{* *} 5 \%$ and ${ }^{* * *}$ $1 \%$ level, JCS: Job creation schemes, U: Unemployment, E: Employment

Source: LMM-SA, 1997-1999, own computations

\subsection{Sensitivity Analysis}

In a first sensitivity analysis we extend on the analysis with respect to the heterogeneity of treatment effects. We additionally allow for a random coefficient for the treatment effect similar to Richardson and van den Berg (2013). It turns out that the model fit evaluated on the basis of the AIC and the BIC does not improve compared to a model with a homogenous treatment effect. This implies that the model not allowing for random treatment effects is the preferred specification. ${ }^{19}$

We perform several modifications of the unemployment and treatment definition to check the robustness of our results. An overview of the estimated treatment effects for the different

\footnotetext{
${ }^{18}$ This result is in accordance with the results found by Bergemann, Fitzenberger, and Speckesser (2009).

${ }^{19}$ Results of the model with a random coefficient for the treatment effect are reported in the Appendix (see Table B.5). The Log-likelihood of this model specification amounts to $-8,671$.
} 
specifications can be found in Table 9. All these sensitivity analyses are conducted for the bivariate duration model consisting of the duration until treatment and duration until transition to work.

First, we include participants in Mega-JCS in our analysis. This type of job creation scheme is described in Section 2.3. These cases are defined by a direct transition from employment into the program. The data reveal 180 participations in Mega-JCS. We estimate two different specifications: first, we include an "artificial" month of unemployment only for Mega-job creation scheme participants and second, we extend each unemployment spell by an "artificial" month of unemployment. In both cases, the optimal model specification is based on four mass points and we find a significant negative treatment effect in the first 11 months and a (negative) insignificant effect after 11 months after program entry. The negative point estimate might stem from longer program durations of Mega-JCS compared to other types of JCS: the mean program duration amounts to 25 months and the median to 24 months.

A further sensitivity analysis deals with the definition of treated unemployment spells. In the baseline specification the treatment indicator is equal to one if an individual participates at least once in a job creation scheme. Thus, we analyze the effect of the first entry in a program. We modify this definition by defining an unemployment spell as right censored at the moment a second program entry is observed. This exercise does not change the estimation results compared to our baseline specification. In a further specification we treat unemployment spells that end in a transition into nonemployment as right censored. Again, our results are robust. Finally, we define periods in training with previous and subsequent unemployment as periods in unemployment. As a consequence the number of unemployment spells decreases and the length of unemployment spells increases. The estimated effect of participating in a JCS are very similar to our main specification.

\section{Conclusions}

JCS are used in many countries in order to fight high unemployment. This paper focuses on JCS in East Germany during very turbulent economic times, notably the aftermath of the German reunification in 1990. We provide a comprehensive empirical analysis of the employment prospects of participants in JCS based on data of an inflow sample of unemployed workers in one East German region (Sachsen-Anhalt). We use the timing-of-events approach that is very well suited, particularly given the institutional context of our evaluation. Firstly, we do not need to rely on the informational content of the employment history of individuals in order to be able to control of unobserved heterogeneity and secondly the focus on transition rates might be more appropriate given the economy is not in a stable equilibrium.

We analyze whether participation in JCS has an impact on the probability of finding a job and whether the corresponding employment stability is affected by previous participation in JCS. The econometric analysis is based on multivariate duration models. We estimate bivariate 
Table 9: Sensitivity Analysis

\begin{tabular}{|c|c|c|}
\hline & Coefficient & Standard Error \\
\hline \multicolumn{3}{|l|}{ Panel A. Inclusion of Mega-JCS version 1} \\
\hline Effect of JCS in months $1-11$ after program start & $-0.981^{* * *}$ & $(0.17)$ \\
\hline Effect of JCS in months $>11$ after program start & -0.128 & $(0.20)$ \\
\hline \multicolumn{3}{|l|}{ Panel B. Inclusion of Mega-JCS version 2} \\
\hline Effect of JCS in months 1 - 11 after program start & $-1.045^{* * *}$ & $(0.18)$ \\
\hline Effect of JCS in months $>11$ after program start & -0.346 & $(0.20)$ \\
\hline \multicolumn{3}{|l|}{ Panel C. $2^{n} d$ time in JCS treated as right censored } \\
\hline Effect of JCS in months $1-11$ after program start & $-1.116^{* * *}$ & $(0.21)$ \\
\hline Effect of JCS in months $>11$ after program start & 0.285 & $(0.24)$ \\
\hline \multicolumn{3}{|c|}{ Panel C. Transition to nonemployment treated as right censored } \\
\hline Effect of JCS in months 1 - 11 after program start & $-1.209^{* * *}$ & $(0.21)$ \\
\hline Effect of JCS in months $>11$ after program start & 0.177 & $(0.23)$ \\
\hline \multicolumn{3}{|c|}{ Panel D. Periods in training defined as periods in unemployment } \\
\hline Effect of JCS in months 1 - 11 after program start & $-0.957^{* * *}$ & $(0.21)$ \\
\hline Effect of JCS in months $>11$ after program start & 0.188 & $(0.23)$ \\
\hline
\end{tabular}

models based on the transition rates from unemployment to JCS and from unemployment to work, and models with three transition processes taking additionally into account the transition rate from employment back to unemployment. Our approach allows to control for selection into treatment based on both observable and unobservable characteristics.

In parts our findings are in accordance to results in more stable economies. We find on average strong locking-in effects of participation in JCS. As found before, this strong negative effect on the probability of finding a regular job vanishes after the typical program duration of one year and stays close to zero thereafter. However, in contrast to findings in more stable economies our results suggest that highly skilled women benefit from participation. Another important result which is new to the literature concerns the stability of jobs after participation. We do not find that the job retention rates are influenced by JCS; not on average and also not if effect heterogeneity is taken into account. Additionally, we find weak evidence that also long-term unemployed gain from participation in JCS.

These results add to the so far scarce evidence on the effectiveness of JCS in transformation economies. Additionally, the findings show that it is important to not transfer the negative evaluation results on job creation schemes that are found for stable and rather mature economies to situations that are more turbulent. In situations with high job destruction rates other and/or additional labor market groups might benefit from participation in job creation schemes. It seems likely that this conclusion transfers to other economic crisis than the transformation process. 


\section{References}

Abbring, Jaap H. and Gerard J. van den Berg (2003). "The nonparametric identification of treatment effects in duration models". In: Econometrica 71.5, pp. 1491-1517.

Aitkin, Murray (1999). “A general maximum likelihood analysis of variance components in generalized linear models". In: Biometrics 55.1, pp. 117-128.

Bergemann, Annette, Bernd Fitzenberger, and Stefan Speckesser (2009). "Evaluating the dynamic employment effects of training programs in East Germany using conditional difference-in-differences”. In: Journal of Applied Econometrics 24.5, pp. 797-823.

Bergemann, Annette and Gerard J. van den Berg (2008). “Active Labor Market Policy Effects for Women in Europe - A Survey”. In: Annales d'Economie et de Statistique, pp. 385-408.

Bonnal, Liliane, Denis Fougère, and Anne Sérandon (1997). "Evaluating the impact of French employment policies on individual labour market histories". In: The Review of Economic Studies 64.4, pp. 683-713.

Brinkmann, Christian and Brigitte Völkel (1992). "Zur Implementation arbeitsmarktpolitischer Maßnahmen in den neuen Bundesländern.” In: Mitteilungen aus der Arbeitsmarkt- und Berufsforschung 25.3, pp. 260-276.

Burda, Michael C. and Jennifer Hunt (2001). "From reunification to economic integration: productivity and the labor market in Eastern Germany". In: Brookings Papers on Economic Activity 2001.2, pp. 1-71.

Caliendo, Marco, Reinhard Hujer, and Stephan L. Thomsen (2006). "Sectoral heterogeneity in the employment effects of job creation schemes in Germany". In: Jahrbücher für Nationalökonomie und Statistik, pp. 139-179.

Caliendo, Marco, Reinhard Hujer, and Stephan L. Thomsen (2008a). "The Employment Effects of Job Creation Schemes in Germany-A Microeconometric Evaluation”. In: Modelling and Evaluating Treatment Effects in Econometrics. Ed. by Daniel Millimet, Jeffery A. Smith, and Edward Vytlacil. Vol. 21. Oxford: Elsevier Science, pp. 381-428.

Caliendo, Marco, Reinhard Hujer, and Stephan L. Thomsen (2008b). "Identifying effect heterogeneity to improve the efficiency of job creation schemes in Germany". In: Applied Economics 40.9, pp. 1101-1122.

Caliendo, Marco, Steffen Künn, and Arne Uhlendorff (2016). "Earnings Exemptions for Unemployed Workers: The Relationship between Marginal Employment, Unemployment Duration and Job Quality". In: Labour Economics, forthcoming.

Card, David, Jochen Kluve, and Andrea Weber (2010). "Active labour market policy evaluations: A meta-analysis". In: The Economic Journal 120.548, F452-F477.

Cockx, Bart and Geert Ridder (2001). "Social employment of welfare recipients in Belgium: an evaluation". In: The Economic Journal 111.470, pp. 322-352. 
Crépon, Bruno, Marc Ferracci, Grégory Jolivet, and Gerard J Van den Berg (2010). “Analyzing the anticipation of treatments using data on notification dates". In: IZA Discussion Paper 5265.

Eichler, Martin and Michael Lechner (2002). "An evaluation of public employment programmes in the East German State of Sachsen-Anhalt.” In: Labour Economics 9.2, pp. 143-186.

Gaure, Simen, Knut Røed, and Tao Zhang (2007). "Time and causality: A Monte Carlo assessment of the timing-of-events approach". In: Journal of Econometrics 141.2, pp. 1159-1195.

Heckman, James J. and Salvador Navarro (2007). "Dynamic discrete choice and dynamic treatment effects.” In: Journal of Econometrics 136.2, pp. 341-396.

Hohmeyer, Katrin and Joachim Wolff (2012). “A fistful of euros: Is the German one-euro job workfare scheme effective for participants?" In: International Journal of Social Welfare 21.2, pp. 174-185.

Honoré, Bo E. (1993). "Identification results for duration models with multiple spells". In: The Review of Economic Studies 60.1, pp. 241-246.

Hübler, Olaf (1997). "Evaluation beschäftigungspolitischer Maßnahmen in Ostdeutschland/An Evaluation of Employment Measures in Eastern Germany”. In: Jahrbücher für Nationalökonomie und Statistik 216.1, pp. 21-44.

Hujer, Reinhard, Marco Caliendo, and Stephan L. Thomsen (2004). "New evidence on the effects of job creation schemes in Germany - a matching approach with threefold heterogeneity". In: Research in Economics 58.4, pp. 257-302.

Hujer, Reinhard and Stephan L. Thomsen (2010). "How do the employment effects of job creation schemes differ with respect to the foregoing unemployment duration?" In: Labour Economics 17.1, pp. 38-51.

Hujer, Reinhard and Christopher Zeiss (2007). "The effects of job creation schemes on the unemployment duration in Eastern Germany." In: Zeitschrift für ArbeitsmarktForschung Journal for Labour Market Research 40.4, pp. 383-398.

Kluve, Jochen, Hartmut Lehmann, and Christoph M. Schmidt (1999). “Active labor market policies in Poland: human capital enhancement, stigmatization, or benefit churning?" In: Journal of Comparative Economics 27.1, pp. 61-89.

Kraus, Florian, Patrick A. Puhani, and Viktor Steiner (2000). "Do public works programs work? Some unpleasant results from the East German experience." In: Research in Labor Economics. Ed. by Solomon Polachek and John Robst. Greenwich: JAI Press.

Kröhnert, Steffen and Samuel Skipper (2010). "Demographic Development in Eastern Germany". In: Berlin: Berlin-Institut für Bevölkerung und Entwicklung.

Lalive, Rafael, Jan C. van Ours, and Josef Zweimüller (2008). "The impact of active labour market programmes on the duration of unemployment in Switzerland". In: The Economic Journal 118.525, pp. 235-257. 
Lubyova, Martina and Jan C. van Ours (1999). "Effects of active labor market programs on the transition rate from unemployment into regular jobs in the Slovak Republic". In: Journal of Comparative Economics 27.1, pp. 90-112.

Puhani, Patrick A. (2002). "Advantage through training in Poland? A microeconometric evaluation of the employment effects of training and job subsidy programmes". In: Labour 16.3, pp. 569-608.

Richardson, Katarina and Gerard J. van den Berg (2013). "Duration dependence versus unobserved heterogeneity in treatment effects: Swedish labor market training and the transition rate to employment.” In: Journal of Applied Econometrics 28.2, pp. 325-351.

Spitznagel, Eugen (1992). "Allgemeine Maßnahmen zur Arbeitsbeschaffung (ABM) in den neuen Bundesländern.” In: Mitteilungen aus der Arbeitsmarkt- und Berufsforschung 25.3, pp. 277-288.

Van den Berg, Gerard J. and Johan Vikström (2014). "Monitoring job offer decisions, punishments, exit to work, and job quality". In: The Scandinavian Journal of Economics 116.2, pp. 284-334.

Von Hagen, Jürgen, Rolf R. Strauch, and Guntram B. Wolff (2002). "East Germany: Transition with Unification; Experiments and Experiences”. In: ZEI Working Papers B.19-2002.

Völkel, Brigitte (1994). "Implementation von Arbeitsbeschaffungsmaßnahmen (ABM) in den neuen Bundesländern - Erfahrungen, Probleme, Forschungsbedarf." In: Mitteilungen aus der Arbeitsmarkt- und Berufsforschung 27.4, pp. 359-371.

Wunsch, Conny (2005). "Labour market policy in Germany: institutions, instruments and reforms since unification”. In: University of St. Gallen Economics Discussion Paper 2005-06. 


\section{Appendix}

\section{A Data and Descriptive Statistics}

Table A.1: Definitions of Variables

\begin{tabular}{|c|c|c|}
\hline Variable & Definition & Time Varying? \\
\hline Treatment & $\begin{array}{l}\text { Dummy for participating in a job creation } \\
\text { scheme for the first time }\end{array}$ & Time Varying \\
\hline \multicolumn{3}{|l|}{ Individual characteristics: } \\
\hline Age Groups: & $\begin{array}{l}\text { Dummies for being in corresponding age } \\
\text { group during observation period }\end{array}$ & Time Varying \\
\hline Ages 25-29 & Aged between 25 and 29 & Time Varying \\
\hline Ages 30-34 & Aged between 30 and 34 & Time Varying \\
\hline Ages 35-39 & Aged between 35 and 39 & Time Varying \\
\hline Ages 40-44 & Aged between 40 and 44 & Time Varying \\
\hline Ages 45-50 & Aged between 45 and 50 & Time Varying \\
\hline Ages $>50$ & Aged 50 and older & Time Varying \\
\hline Female & Dummy for being female & Constant \\
\hline Professional Education: & $\begin{array}{l}\text { Dummies for highest professional education } \\
\text { level in } 1990\end{array}$ & Constant \\
\hline No Vocational Training & No Vocational Training & Constant \\
\hline Partly Vocational Training & Partly Vocational Training (Teilfacherbeiter) & Constant \\
\hline Vocational Training & Vocational Training (Facharbeiter) & Constant \\
\hline Advanced Vocational Training & $\begin{array}{l}\text { Advanced Vocational Training (Meister, Tech- } \\
\text { niker) }\end{array}$ & Constant \\
\hline Technical College & Technical College (Fachschule) & Constant \\
\hline University Degree & $\begin{array}{l}\text { University Degree (Universität, Fach- } \\
\text { hochschule) }\end{array}$ & Constant \\
\hline Regions: & $\begin{array}{l}\text { Dummies for living in one of eight } \\
\text { labor market districts of Sachsen-Anhalt }\end{array}$ & Constant \\
\hline Dessau & Dessau & Constant \\
\hline Halberstadt & Halberstadt & Constant \\
\hline Halle & Halle & Constant \\
\hline Magdeburg & Magdeburg & Constant \\
\hline Merseburg & Merseburg & Constant \\
\hline Sangerhausen & Sangerhausen & Constant \\
\hline Stendal & Stendal & Constant \\
\hline Wittenberg & Wittenberg & Constant \\
\hline Year Dummies & $\begin{array}{l}\text { Dummies indicating the current year, } \\
\text { ranging from 1991-1998 }\end{array}$ & Time varying \\
\hline Quarter Dummies & $\begin{array}{l}\text { Dummies indicating the current quarter of the } \\
\text { year }\end{array}$ & Time varying \\
\hline
\end{tabular}
year 
Table A.1: Definitions of Variables (Continuation)

\begin{tabular}{|c|c|c|}
\hline Variable & Definition & Time Varying? \\
\hline Unemployment rate & $\begin{array}{l}\text { Monthly unemployment rates by labor } \\
\text { market districts }\end{array}$ & Time varying \\
\hline Unemployment rate squared & $\begin{array}{l}\text { Monthly unemployment rates by labor } \\
\text { market districts squared }\end{array}$ & Time varying \\
\hline $\begin{array}{l}\text { Dummy for remaining } \\
\text { unemployment benefit claims }\end{array}$ & $\begin{array}{l}\text { Dummy for months of remaining benefit } \\
\text { claims }\end{array}$ & Time varying \\
\hline $\begin{array}{l}\text { Remaining unemployment } \\
\text { benefit claims }\end{array}$ & Months of remaining benefit claims & Time varying \\
\hline $\begin{array}{l}\text { Remaining unemployment } \\
\text { benefit claims squared }\end{array}$ & Months of remaining benefit claims squared & Time varying \\
\hline
\end{tabular}

Note: The time constant explanatory variables are measured at the date of the interview.

Source: LMM-SA, 1997-1999, own computations 
Table A.2: Labor Market Transitions in \%

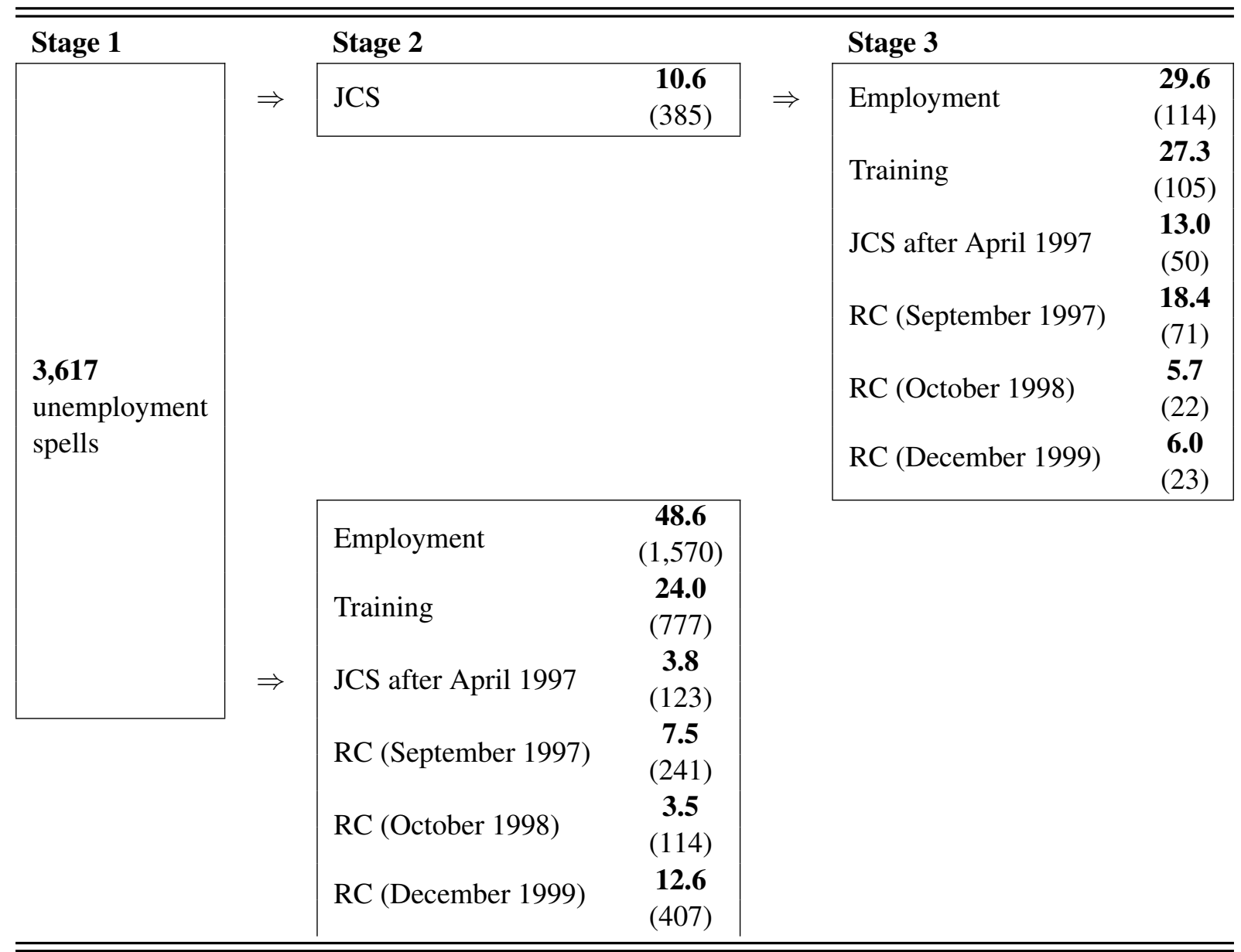

Note: Absolute values are in parentheses, JCS: Job creation schemes, RC: Right censoring due to end of observation period which can be September 1997, October 1998 or December 1999 depending on the wave of the survey, transitions to training and to JCS that started after April 1997 are treated as right censored.

Source: LMM-SA, 1997-1999, own computations 
Table A.3: Descriptive Statistics of Durations

\begin{tabular}{|c|c|c|c|c|c|c|c|c|}
\hline & $\mathrm{N}$ & Mean & S.D. & Min & $\begin{array}{c}25 \% \\
\text { Quantile }\end{array}$ & Median & $\begin{array}{c}75 \% \\
\text { Quantile }\end{array}$ & Max \\
\hline $\begin{array}{l}\text { Number of spells } \\
\text { per individual }\end{array}$ & 2,088 & 1.73 & 1.01 & 1 & 1 & 1 & 2 & 7 \\
\hline $\begin{array}{l}\text { Number of treatments } \\
\text { per treated spells }\end{array}$ & 385 & 1.19 & 0.45 & 1 & 1 & 1 & 1 & 3 \\
\hline \multicolumn{9}{|l|}{ Durations: } \\
\hline $\begin{array}{l}\text { Unemployment duration } \\
\text { (complete spell) }\end{array}$ & 1,933 & 19.30 & 19.81 & 1 & 5 & 12 & 26 & 107 \\
\hline $\begin{array}{l}\text { Unemployment duration } \\
\text { (rc spell) }\end{array}$ & 1,684 & 9.26 & 10.65 & 1 & 2 & 5 & 12 & 85 \\
\hline $\begin{array}{l}\text { Program duration } \\
\text { (complete spell) }\end{array}$ & 168 & 12.48 & 8.39 & 1 & 7 & 12 & 13 & 60 \\
\hline $\begin{array}{l}\text { Program duration } \\
\text { (rc spell) }\end{array}$ & 413 & 15.11 & 9.54 & 1 & 11 & 12 & 15 & 60 \\
\hline $\begin{array}{l}\text { Subsequent employment } \\
\text { duration (complete spell) }\end{array}$ & 818 & 17.14 & 17.24 & 1 & 5 & 11 & 23 & 104 \\
\hline $\begin{array}{l}\text { Subsequent employment } \\
\text { duration (rc spell) }\end{array}$ & 866 & 38.55 & 28.08 & 1 & 13 & 32 & 62 & 107 \\
\hline
\end{tabular}

Note: S.D.: Standard deviation, rc: Right censored

Source: LMM-SA, 1997-1999, own computations 


\section{B Estimation Results}

Table B.1: Tests for Unobserved Heterogeneity

\begin{tabular}{lcccc}
\hline \hline Unobserved heterogeneity & 0 mass points & 2 mass points & 3 mass points & 4 mass points \\
\hline Log likelihood & $-8,809.8$ & $-8,693.7$ & $-8,671.5$ & $-8,670.3$ \\
AIC & $17,787.6$ & $17,561.4$ & $17,522.9$ & $17,526.6$ \\
BIC & $18,261.7$ & $18,052.4$ & $18,030.9$ & $18,051.5$ \\
\hline \hline
\end{tabular}

Source: LMM-SA, 1997-1999, own computations

Figure B.1: Empirical and Predicted Exit Rate to Work

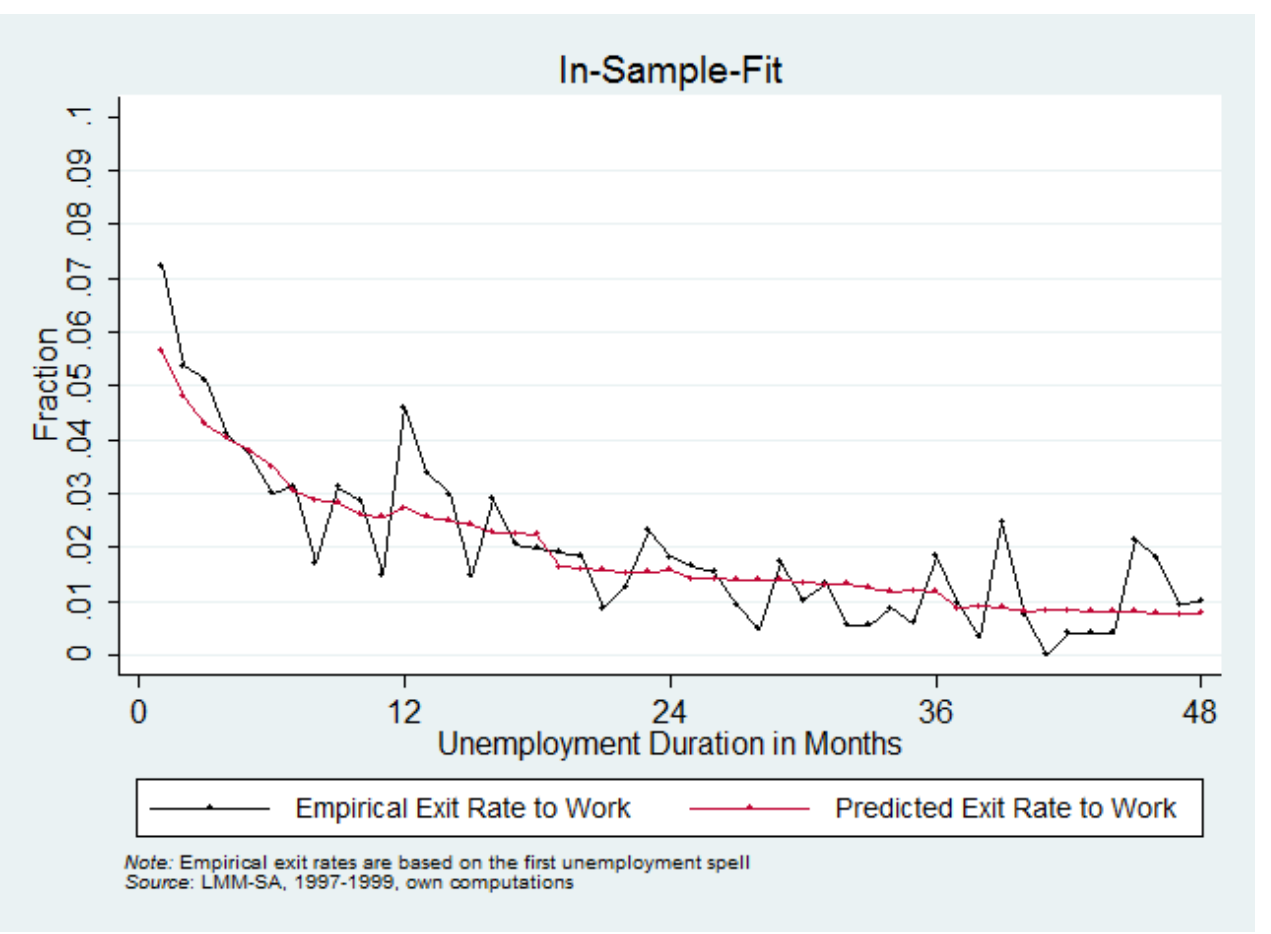


Table B.2: Effect of JCS for High Skilled Women

\begin{tabular}{llc}
\hline \hline & \multicolumn{1}{c}{ Coefficient } & Standard Error \\
\hline Effect of JCS in months $1-11$ after program start & $-1.862^{* * *}$ & $(0.37)$ \\
Effect of JCS in months $>11$ after program start & -0.464 & $(0.36)$ \\
Effect of JCS $\quad \times$ Female & $0.880^{* *}$ & $(0.39)$ \\
Effect of JCS $\quad \times$ High Skilled & $0.943^{* *}$ & $(0.40)$ \\
Effect of JCS $\quad \times$ Female $\quad \times$ High Skilled & -0.593 & $(0.52)$ \\
\hline \hline
\end{tabular}

Note: Standard errors are in parentheses, coefficients are statistically significant at the ${ }^{*} 10 \%,{ }^{* *} 5 \%$ and ${ }^{* * *} 1 \%$ level, JCS: Job creation schemes

Source: LMM-SA, 1997-1999, own computations

Table B.3: Time dependent Effect of JCS for Model with Three Transition Rates

\begin{tabular}{|c|c|c|c|c|}
\hline & \multicolumn{2}{|c|}{$\begin{array}{c}\text { Transition } \\
\qquad U \rightarrow E\end{array}$} & \multicolumn{2}{|c|}{$\begin{array}{c}\text { Transition } \\
\qquad E \rightarrow U\end{array}$} \\
\hline & Coef. & S.E. & Coef. & S.E. \\
\hline \multicolumn{5}{|l|}{ Panel A. Effect of JCS dependent on Time Since Start } \\
\hline Effect of JCS in months 1 - 11 after program start & $-1.139^{* * *}$ & $(0.21)$ & 0.356 & $(0.25)$ \\
\hline Effect of JCS in months 12 - 13 after program start & 0.346 & $(0.32)$ & -0.582 & $(0.72)$ \\
\hline Effect of JCS in months 14 - 23 after program start & -0.042 & $(0.25)$ & 0.157 & $(0.36)$ \\
\hline Effect of JCS in months 24 - 25 after program start & $1.224^{* * *}$ & $(0.38)$ & 0.161 & $(0.60)$ \\
\hline Effect of JCS in months $>25$ after program start & 0.285 & $(0.35)$ & 0.358 & $(0.44)$ \\
\hline \multicolumn{5}{|c|}{$\begin{array}{l}\text { Panel B. Effect of JCS dependent on Year of Start of Participation } \\
\text { Start occurs in year } 1991 \text { or } 1992\end{array}$} \\
\hline Effect of JCS in months 1 - 11 after program start & $-1.097^{* * *}$ & $(0.35)$ & 0.005 & $(0.42)$ \\
\hline $\begin{array}{l}\text { Effect of JCS in months }>11 \text { after program start } \\
\text { Start occurs in year } 1993 \text { or } 1994\end{array}$ & 0.280 & $(0.35)$ & 0.279 & $(0.35)$ \\
\hline Effect of JCS in months 1 - 11 after program start & $-1.008^{* * *}$ & $(0.35)$ & 0.363 & $(0.40)$ \\
\hline $\begin{array}{l}\text { Effect of JCS in months }>11 \text { after program start } \\
\text { Start occurs in year } 1995 \text { or } 1996 \text { or } 1997\end{array}$ & 0.202 & $(0.31)$ & 0.191 & $(0.39)$ \\
\hline Effect of JCS in months 1 - 11 after program start & $-1.332^{* * *}$ & $(0.37)$ & $0.876^{*}$ & $(0.46)$ \\
\hline Effect of JCS in months $>11$ after program start & 0.174 & $(0.28)$ & -0.778 & $(0.70)$ \\
\hline
\end{tabular}

Note: Standard errors (S.E.) are in parentheses, coefficients are statistically significant at the ${ }^{*} 10 \%,{ }^{* *} 5 \%$ and ${ }^{* * *}$ 1\% level, JCS: Job creation schemes, U: Unemployment, E: Employment

Source: LMM-SA, 1997-1999, own computations 
Table B.4: Effect of JCS dependent on observed Characteristics for Model with Three Transition Rates

\begin{tabular}{|c|c|c|c|c|c|}
\hline & & \multicolumn{2}{|c|}{$\begin{array}{l}\text { Transition } \\
\qquad \rightarrow E\end{array}$} & \multicolumn{2}{|c|}{$\begin{array}{c}\text { Transition } \\
E \rightarrow U\end{array}$} \\
\hline & & Coef. & S.E. & Coef. & S.E. \\
\hline \multicolumn{2}{|c|}{ Effect of JCS in months 1 - 11 after program start } & $-1.658^{* * *}$ & $(0.35)$ & 0.460 & $(0.43)$ \\
\hline \multicolumn{2}{|c|}{ Effect of JCS in months $>11$ after program start } & -0.298 & $(0.35)$ & 0.156 & $(0.38)$ \\
\hline Effect of JCS & $\times$ Female & $0.515^{*}$ & $(0.28)$ & -0.007 & $(0.37)$ \\
\hline Effect of JCS & $\times$ Age $>45$ & -0.168 & $(0.27)$ & -0.267 & $(0.36)$ \\
\hline Effect of JCS & $\times$ High skilled & $0.592^{* *}$ & $(0.26)$ & 0.038 & $(0.38)$ \\
\hline
\end{tabular}

Note: Standard errors (S.E.) are in parentheses, coefficients are statistically significant at the ${ }^{*} 10 \%,{ }^{* *} 5 \%$ and ${ }^{* * *}$ $1 \%$ level, JCS: Job creation schemes, U: Unemployment, E: Employment

Source: LMM-SA, 1997-1999, own computations

Table B.5: Effect of JCS dependent on unobserved Characteristics

\begin{tabular}{lcc}
\hline \hline & Coefficient & Standard Error \\
\hline Effect of JCS in months $>11$ after program start & $1.341^{* * *}$ & $(0.28)$ \\
Effect of JCS & $-1.152^{* *}$ & $(0.50)$ \\
Unobserved heterogeneity in treatment effect: & & \\
$v_{2}-v_{1}$ & 0.447 & $(0.28)$ \\
$v_{3}-v_{1}$ & $-0.474^{*}$ & $(0.26)$ \\
\hline \hline
\end{tabular}

Note: Standard errors are in parentheses, coefficients are statistically significant at the ${ }^{*} 10 \%,{ }^{* *} 5 \%$ and ${ }^{* * *} 1 \%$ level, JCS: Job creation schemes

Source: LMM-SA, 1997-1999, own computations 